\title{
Swiss Courts and Treaty Interpretation
}

Those who draft Conventions, and those of us who comment upon them, would do well to remember that the canons of interpretation $[\ldots]$ are every bit as worthy of our efforts as the substantive rules of international law on which attention has been more liberally lavished. ${ }^{1370}$

S'agissant de l'interprétation des traités, la Convention de Vienne du 23 mai 1969 sur le droit des traités (RS o.111) pose des principes directeurs, qui sont relativement semblables aux méthodes d'interprétation valant pour les règles générales et abstraites en droit interne, au nombre desquelles figurent les traités internationaux qui, en Suisse, sont introduits dans l'ordre juridique national dès leur entrée en vigueur sur le plan du droit international (cf. ATF $135 \mathrm{~V}$ 339 consid. 5.3; ATF 13 I I 312 consid. 4.1 p. 325). Sur le plan interne, la loi s'interprète selon sa lettre, son esprit et son but, ainsi que selon les valeurs sur lesquelles elle repose, conformément à la méthode téléologique; si la prise en compte d'éléments historiques n'est pas déterminante pour l'interprétation, cette dernière doit néanmoins s'appuyer en principe sur la volonté du législateur et sur les jugements de valeur qui la sous-tendent de manière reconnaissable (cf. ATF 135 III 20 consid. 4.4 p. 23).1371

Introduction

The law of treaties represents the great bulk of the domestic judicial practice of international law. This also applies to the Swiss practice, as empirical findings show. ${ }^{1372}$

1370 Foxton (n 188) 291.

1371 Swiss Federal Tribunal, BGE 136 I 290, at 2.3.2.

1372 Ammann, 'International Law in Domestic Courts Through an Empirical Lens: The Swiss Federal Tribunal's Practice of International Law in Figures' ( $n_{5}$ ).

(C) ODILE AMMANN, 2020 | DOI:10.1163/9789004409873_009

This is an open access chapter distributed under the terms of the CC-BY-NC 4.o License: le Ammann - 9789004409873 Downloaded from Brill.com04/26/2023 08:49:14AM 
Treaties ratified by Switzerland span a wide number of substantive areas, ${ }^{1373}$ including IHRL, migration, diplomatic relations, copyright, civil aviation, and investment protection, and including both public and private international law. ${ }^{1374}$ Treaties can be bilateral or multilateral. They can provide short-term answers to specific issues, or establish long-term cooperative schemes. They can generate interstate or intrastate rights and duties.

'[T]reaties', Philip Muntz reportedly said in the House of Commons in 1871, 'like piecrusts, [...] were made to be broken, and always had been broken when opportunities presented themselves to the aggrieved parties to renounce the obligations they imposed.. 1375 Due to the characteristics of international lawmaking and adjudication and to the frequent vagueness of international law, including treaty law, domestic courts, when they interpret treaties, may disregard the interpretative methods required by international law (on these methods, see Chapter 6, supra). It is also important to recall that domestic rulings provide evidence of the constitutive elements of CIL and, hence, of customary methods of treaty interpretation. Courts may therefore be tempted to (erroneously) $)^{1376}$ rely on their own case law when stating what these interpretative methods require.

In this chapter, I examine the extent to which Swiss courts (i) respect the methods of treaty interpretation required by international law and (ii) interpret treaties in a predictable, clear, and consistent way. ${ }^{1377}$ I show that their practice sometimes runs afoul of these criteria and virtues. In the concluding section of this book (infra, Conclusion and Recommendations), I suggest ways in which this practice must (from the perspective of international law) and should (from the perspective of good judicial reasoning) be improved.

Many of the difficulties pointed out in this chapter are not unique to the Swiss judiciary: similar problems exist in other jurisdictions. I briefly refer to this foreign practice to put the Swiss case law into perspective (infra, section 2). Given how laborious a study of the case law in other States would be, I mostly rely on scholarly syntheses and on the ILDC database.

$1373<$ www.eda.admin.ch/eda/de/home/aussenpolitik/voelkerrecht/internationalevertraege/datenbank-staatsvertraege.html>.

1374 As previously mentioned, this study primarily focuses on public international law, while taking private international law into account (supra, Chapter 2, section 5).

1375 HC Deb 30 March 1871, vol 205, cols 894-976, at 927. The authorship of this quote is disputed: some attribute it to Lenin, others to Jonathan Swift.

${ }_{137}$ The practice of one court, to become legally authoritative on the international plane, must be part of a coherent, constant, and general practice.

1377 On these two criteria of evaluation, see supra, Introduction, 3. 
I first provide a short (and, given the breadth of the issue, inevitably schematic) overview of domestic courts' approach to treaty interpretation in general (2). I then zoom in on Swiss courts. I expose and assess the methods they use, and the reasons they provide in support of their interpretations (3). I close with a general evaluation of their case law (4), based on the aforementioned criteria of legality and quality.

It is difficult to do justice to Swiss courts' multi-faceted practice of treaty interpretation in one chapter. I hence focus on the features of the case law that are the most prominent and problematic from the perspective of my two criteria of evaluation. I will not dwell upon the status, rank, and direct effect of treaties in the Swiss legal order. This question has been addressed in Chapter 3 (supra).

The present chapter takes the practice of the Swiss Federal Tribunal into account. It also includes - subject to availability - rulings of other federal and cantonal courts, ie, the Swiss Federal Administrative Court, the Swiss Federal Criminal Court, the highest courts of the cantons of Geneva, Zurich, BaselStadt, and Bern, and decisions of the Swiss military tribunals. (On the structure of the Swiss judiciary, see supra, Chapter 3, 4.1.) For the purposes of my inquiry, I relied on these courts' official websites. For the Swiss Federal Tribunal, I mainly worked with the database of rulings published in the Court's official compendium since 1954, and with its expert search mode. ${ }^{1378}$ I also included rulings not published in the official compendium and issued since 2000.1379 I used the advanced search function of the Swisslex database, ${ }^{1380}$ which contains, inter alia, cantonal decisions published in Swiss law journals, and which makes it possible to look up decisions mentioning art. $31 \mathrm{f} \mathrm{VCLT.} \mathrm{The} \mathrm{case} \mathrm{law}$ on which this chapter is based reflects the state of courts' online databases or websites in June 2019 .

Apart from the case law of the Swiss Federal Tribunal, the Swiss rulings I analyze are fairly recent, either because only newer rulings are accessible online (which applies to cantonal courts), or because the institutional history

1378 I searched for terms such as 'Auslegung AND 20 Wiener AND 20 Staatsvertrag', or 'Auslegung AND 25 Staatsvertrag', which brought up citations of these keywords when the keywords were separated by at most 20 (or 25) words. In addition, I restricted the time period of my search (from 1954 to 1980 , from 198 o to 1990, and from 1990 onwards), in accordance with the three phases in the Swiss case law studied in section 3 .

1379 On this database, see Ammann, 'International Law in Domestic Courts Through an Empirical Lens: The Swiss Federal Tribunal's Practice of International Law in Figures' (n 5). The database can be accessed at <www.bger.ch/index/juridiction/jurisdictioninherit-template/jurisdiction-recht/jurisdiction-recht-urteile2ooo.htm >.

$1380<$ swisslex.ch $>$. 
of some judicial bodies is relatively short (this concerns federal courts other than the Swiss Federal Tribunal, see supra, Chapter 3, 4.1.1.2-4.1.1.3). My study is hence selective, and its findings pertaining to the practice of the abovementioned Swiss courts cannot be extrapolated to the entire Swiss practice (and, of course, even less to that of domestic courts across the globe) without the necessary caveats.

Domestic Courts and the Methods of Treaty Interpretation

\subsection{Introductory Remarks}

In this section, my goal is two-fold. First, I determine whether domestic courts respect the interpretative methods required by international law when interpreting treaties. I also evaluate the quality of their interpretations. The two perspectives will often be intermingled. I do not to conduct a full-fledged study in comparative law. My aim is simply to put Swiss courts' practice of treaty interpretation into perspective (infra, 3.6).

To evaluate the legality and quality of the practice of domestic courts in various States is a daunting task. As of June 2019, the UN counted 193 Member States, and each of them is connected to other subjects of international law through an array of treaties. Instead of offering a comprehensive overview of this treaty practice, I discuss and assess its characteristics in broad brushstrokes. Moreover, I merely analyze courts' general hermeneutic approach. Reasons of scope, and the lack of detailed scholarship on the issue, preclude looking at domestic courts' use of individual methods.

For the purposes of this study, I use several scholarly syntheses. I focus on work published in 2000 or later, as it is more likely to take into account changes that have occurred in the practice across time. In most cases, the works I rely on describe a State's judicial practice in general, and not with regard to specific areas of international law. ${ }^{1381}$ To provide an overview of

1381 Some of the analyses on which I rely concern a particular substantive area of international law, eg Sanzhuan Guo, 'Implementation of Human Rights Treaties by Chinese Courts: Problems and Prospects' (2009) 8 Chinese Journal of International Law 161; Marochkin and Popov (n 183); Izelle Du Plessis, 'Some Thoughts on the Interpretation of Tax Treaties in South Africa' (2012) 24 South African Mercantile Law Journal 31; Bernhardt Laurentius Johannes, The Interpretation of South African Double Taxation Agreements Under International Law (University of Pretoria 2013); Urs Linderfalk, 'When the International Lawyers Get to Be Heard: The Story of Tax Treaty Interpretation as Told in Sweden' (2016) Nordic Tax Journal 3. 
domestic case law that is as geographically balanced as possible, I look at scholarship pertaining to African, ${ }^{1382}$ Asian, ${ }^{1383}$ European, ${ }^{1384}$ North ${ }^{1385}$ and South

1382 Dire Tladi, 'Interpretation of Treaties in an International Law-Friendly Framework: The Case of South Africa' in Helmut Philipp Aust and Georg Nolte (eds), The Interpretation of International Law by Domestic Courts: Unity, Diversity, Convergence (Oxford University Press 2016); Dugard (n 360); Nicholas Wasonga Orago, 'The 2010 Kenyan Constitution and the Hierarchical Place of International Law in the Kenyan Domestic Legal System: A Comparative Perspective' (2013) 13 African Human Rights Law Journal 415; Du Plessis (n 1381); Johannes (n 1381).

1383 Congyan (n 44); Sanzhuan (n 1381); Yukiko Takashiba, 'Gingerly Walking on the VCLT Frontier? Reflections From a Survey on the Interpretive Approach of the Japanese Courts to Treaties' in Helmut Philipp Aust and Georg Nolte (eds), The Interpretation of International Law by Domestic Courts: Unity, Diversity, Convergence (Oxford University Press 2016); Vivek Kanwar, “Treaty Interpretation in Indian Courts: Adherence, Coherence, and Convergence' in Helmut Philipp Aust and Georg Nolte (eds), The Interpretation of International Law by Domestic Courts: Unity, Diversity, Convergence (Oxford University Press 2016); Marochkin and Popov (n 183); William E Butler, 'Russian Federation' in David L Sloss (ed), The Role of Domestic Courts in Treaty Enforcement: A Comparative Study (Cambridge University Press 2009); David Kretzmer, 'Israel' in David L Sloss (ed), The Role of Domestic Courts in Treaty Enforcement: A Comparative Study (Cambridge University Press 2009); Nihal Jayawickrama, 'India' in David L Sloss (ed), The Role of Domestic Courts in Treaty Enforcement: A Comparative Study (Cambridge University Press 20o9); Bianca Karim, 'Bangladesh' in Dinah Shelton (ed), International Law and Domestic Legal Systems: Incorporation, Transformation, and Persuasion (Oxford University Press 2011); Jerry Z Li and Sanzhuan Guo, 'China' in Dinah Shelton (ed), International Law and Domestic Legal Systems: Incorporation, Transformation, and Persuasion (Oxford University Press 2011 ); Farshad Rahimi Dizgovin, 'Enforcement of International Treaties by Domestic Courts of Iran: New Developments' (2018) 58 Virginia Journal of International Law 227.

1384 Fatima (n 45); Anthony Aust, 'United Kingdom' in David L Sloss (ed), The Role of Domestic Courts in Treaty Enforcement: A Comparative Study (Cambridge University Press 2009); Callista Harris and Krishna Kakkaiyadi, 'Treaty Interpretation Before the Supreme Court' (2013) 2 Cambridge Journal of International and Comparative Law 113; Lily Alexandra Hands, 'From Assange to Zentai: Interpretative Conjunctions Between International and Domestic Extradition Law in Australia and the United Kingdom' (2015) 15 Oxford University Commonwealth Law Journal 223; Lech Garlicki and Małgorzata MasternakKubiak, 'Poland' in David L Sloss (ed), The Role of Domestic Courts in Treaty Enforcement: A Comparative Study (Cambridge University Press 2009); André Nollkaemper, 'The Netherlands' in David L Sloss (ed), The Role of Domestic Courts in Treaty Enforcement: A Comparative Study (Cambridge University Press 2009); Christian Djeffal, 'Dynamic and Evolutive Interpretation of the ECHR by Domestic Courts? An Inquiry Into the Judicial Architecture of Europe' in Helmut Philipp Aust and Georg Nolte (eds), The Interpretation of International Law by Domestic Courts: Unity, Diversity, Convergence (Oxford University Press 2016); Elisabeth Handl-Petz, 'Austria' in Dinah Shelton (ed), International Law and Domestic Legal Systems: Incorporation, Transformation, and Persuasion (Oxford University Press 2011); Linderfalk (n 1381).

1385 Aust, Rodiles, and Staubach (n 140); Criddle (n 1141); David L Sloss, 'United States' in David L Sloss (ed), The Role of Domestic Courts in Treaty Enforcement: A Comparative Study 
American, ${ }^{1386}$ and Oceanian ${ }^{1387}$ jurisdictions. Of course, the domestic constitutional frameworks governing the relationship between domestic and international law and other features of domestic law (supra, Chapter 3) explain some variations in courts' methods and create issues of comparability across jurisdictions.

My analysis is incomplete because it is largely dependent on preexisting scholarly work, to the extent this work is accessible, both linguistically and practically. Moreover, many scholars do not focus on methods of treaty interpretation. ${ }^{1388}$ Such analyses are needed to provide a comprehensive picture of the domestic case law beyond the 'usual suspects', ie, the United States, the United Kingdom, and other dominant Western States.

Drawing parallels based on foreign scholarship, on the one hand, and Swiss rulings and doctrine (infra, section 3), on the other, raises issues of

(Cambridge University Press 20o9); Gib van Ert, 'Canada' in David L Sloss (ed), The Role of Domestic Courts in Treaty Enforcement: A Comparative Study (Cambridge University Press 20o9); Stéphane Beaulac and John H Currie, 'Canada' in Dinah Shelton (ed), International Law and Domestic Legal Systems: Incorporation, Transformation, and Persuasion (Oxford University Press 2011); McIntyre (n 72 ).

1386 Alejandro Rodiles, 'The Law and Politics of the Pro Persona Principle in Latin America' in Helmut Philipp Aust and Georg Nolte (eds), The Interpretation of International Law by Domestic Courts: Unity, Diversity, Convergence (Oxford University Press 2016); José Antonio Viera Gallo Quesney and Valeria Lübbert Álvarez, 'Los tratados sobre derechos humanos en la jurisprudencia chilena' (2012) 44 Estudios Internacionales 87; Francisco José Eguiguren Praeli, 'Aplicación de los tratados internacionales sobre derechos humanos en la jurisprudencia constitucional peruana' (2003) 9 Ius et Praxis 157; Marisol Peña Torres, 'Los tratados internacionales en la jurisprudencia constitucional' (2003) 1 Estudios constitucionales 593 .

1387 Donald R Rothwell, 'Australia' in David L Sloss (ed), The Role of Domestic Courts in Treaty Enforcement: A Comparative Study (Cambridge University Press 2009); Patrick Wall, 'A Marked Improvement: The High Court of Australia's Approach to Treaty Interpretation in "Macoun v Commissioner of Taxation" [2015] HCA 44' (2016) 17 Melbourne Journal of International Law 170; Alice de Jonge, 'Australia' in Dinah Shelton (ed), International Law and Domestic Legal Systems: Incorporation, Transformation, and Persuasion (Oxford University Press 2011 ); Hands (n 1384); McIntyre (n 72 ).

1388 Joseph Fleuren, 'The Application of Public International Law by Dutch Courts' (2010) 57 Netherlands International Law Review 245; Chilenye Nwapi, 'International Treaties in Nigerian and Canadian Courts' (2011) 19 African Journal of International and Comparative Law 38; Maripe (n 354); Andreas L Paulus, 'Germany' in David L Sloss (ed), The Role of Domestic Courts in Treaty Enforcement: A Comparative Study (Cambridge University Press 2009); Amos O Enabulele, 'Implementation of Treaties in Nigeria and the Status Question: Whither Nigerian Courts?' (2009) 17 African Journal of International and Comparative Law 326. 
comparability. I therefore also consulted rulings on treaty interpretation ${ }^{1389}$ that had been reported in the ILDC database $\mathrm{e}^{1390}$ as of June 2019. I did this (to the extent possible) for the jurisdictions for which I had found relevant scholarship. My goal was not only to have at least roughly comparable units of analysis, but also to corroborate the findings of selected scholarly writings, as one or two scholarly articles are insufficient to draw meaningful conclusions on a State's overall judicial practice.

\subsection{Exposing and Evaluating the Practice}

When analyzing the domestic case law, I distinguish between jurisdictions that are parties to the VCLT (2.2.1), and those that are not (2.2.2). Indeed, although the VCLT's methods bind all States qua CIL, the ratification of the Convention may influence the State's judicial practice. I also identify cross-cutting trends that apply regardless of this distinction (2.2.3).

\subsubsection{Courts of States That Are Parties to the VCLT}

Courts in States that have ratified the vCLT usually mention, and/or acknowledge that they must apply, the Convention's methods of treaty interpretation. ${ }^{1391}$ Gib van Ert for instance notes that the power of Canadian courts to apply these methods is 'well established and uncontroversial.'.1392 English courts have stressed that in principle, domestic law is irrelevant to interpret treaties. ${ }^{1393}$ In Russia, the higher courts have ordered that the lower courts apply the methods of the VCLT, ${ }^{1394}$ and the Supreme Court mentions specific methods in some of its decrees. ${ }^{1395}$ In specific dualist States such as Canada,

1389 The search was facilitated by the 'treaty interpretation' filter and by the jurisdictional filters provided by the database.

1390 One could argue that ILDC entries are scholarly syntheses too. Yet the case summaries, which often consist in a translated or paraphrased version of the ruling, are separate from the scholarly analysis included in the entry.

1391 Rothwell (n 1387) 151 f; van Ert (n 1385) 175; Nollkaemper (n 1384) 361; Aust (n 1384) 483; de Jonge (n 1387) 40; Handl-Petz (n 1384) 84; Fatima (n 45) 81 f; Aldrin De Zilva, 'Treaty Interpretation and Australia's Pre-CGT Tax Treaties' (2002) 31 Australian Tax Review 163, 165. Though it would be excessive to cite them all here, many ILDC entries confirm this statement.

1392 van Ert (n 1385) 181.

1393 Fatima (n 45) $102 \mathrm{ff}$.

1394 Butler (n 1383) 418. See also (regarding 'the operation of treaty rules in time and space') ibid 423 .

1395 See Butler (n 1383) 442. See also the Constitutional Court in Group of Deputies of the State Duma of the Russian Federation, Constitutional proceedings, Judgment No 21-P, ILDC 2455 (RU 2015), 14 July 2015, Russian Federation; Constitutional Court, and the judgment of the Supreme Commercial Court in Sentyabr v. MIA Trans and LSV-Trans 
judges consider that the VCLT's methods also apply to statutes giving effect to treaty obligations. ${ }^{1396}$

Courts do not systematically refer to the VCLT's methods. ${ }^{1397}$ André Nollkaemper notes that Dutch courts seldom mention them, and that they do not consider themselves bound by them. ${ }^{1398}$ Polish courts 'do not directly invoke Article 31 of the Vienna Convention', even if they start from the ordinary meaning of a treaty provision and use many methods the VCLT prescribes. 1399 In Canada, Stéphane Beaulac and John Currie write that the Supreme Court has not cited art. $31 \mathrm{f}$ VCLT for decades because the Court uses the same methods to interpret domestic law. ${ }^{1400}$ In Japan as well, Yukiko Takashiba observes that the State's international legal duty to respect the VCLT's methods (and to respect interpretative methods in general) is not addressed in the case law. ${ }^{1401}$ In Mexico, the Supreme Court does not consistently acknowledge the mandatory character of the VCLT's methods. ${ }^{1402}$

When courts cite the VCLT's methods, they rarely demonstrably follow them ${ }^{1403}$ or provide details as to what methods they are using. ${ }^{1404}$ Many do not dwell on their interpretative approach. ${ }^{1405}$ Courts often apply or emphasize only specific methods, which jeopardizes the predictability, clarity, and

(Joining), Supervision instance, No 15497/12, ILDC 2719 (RU 2013), 23 April 2013, Russian Federation; Supreme Commercial Court.

1396 van Ert (n 1385) 176.

1397 Eg regarding Irish courts: Djeffal (n 1384) 183. On the recent practice of the High Court of Australia: Wall (n 1387) 171.

1398 Nollkaemper (n 1384) 362. For a ruling that conforms to the VCLT's methods without explicitly mentioning them, see $A v$. Secretary of State for Justice, Appeal judgment, LJN: AA8384, AWB 99/6851, JV 2000, 285, ILDC 395 (NL 2000), 26 September 2000, Netherlands; The Hague; District Court. For an explicit mention, see Secretary of State for Finance v. X Incorporated, Final appeal judgment, Case No 35398, LJN: AA7995, ILDC 1073 (NL 2000), BNB 2001/19, 1 November 2000, Netherlands; Supreme Court [HR].

1399 Garlicki and Masternak-Kubiak (n 1384) 387 ff. See also Patent Office of the Republic of Poland v. BC Plc, Final appeal judgment, II GSK 54/05, ONSAiWSA 2006/4/96, ILDC 1528 (PL 2006), 8 February 2006, Poland; Supreme Administrative Court; Question of Law Regarding the Interpretation of Article 17(2) of the Treaty on Extradition Between the Republic of Poland and Australia, Re, Reference to Supreme Court on Preliminary Question, I KZP 47/O2, ILDC 273 (PL 2003), 19 February 2003, Poland; Supreme Court.

1400 Beaulac and Currie (n 1385) $133 \mathrm{f}$.

1401 Takashiba (n 1383) 219. See however ibid 228.

1402 Aust, Rodiles, and Staubach (n 140) 95.

1403 Kretzmer (n 1383) 298; Hands (n 1384) 231. See also the critique of the UK Supreme Court's approach to subsequent practice in Harris and Kakkaiyadi (n 1384) $117 \mathrm{ff}$.

1404 van Ert (n 1385) 18of.

1405 Tladi (n 1382) $143 \mathrm{f}$. See also ibid $150 \mathrm{f}$. 
transparency of their reasoning. They especially stress the 'primacy of the text' based on art. 31(1) VCLT, ${ }^{1406}$ and they fall back on the text when other methods (eg history) ${ }^{1407}$ are inconclusive. While some have deemed the travaux relevant, they have been prudent in appraising them. ${ }^{1408}$ In jurisdictions with separate opinions, the judges' methodological disagreements have come to the fore. ${ }^{1409}$ Courts tend to rely on their own precedents on treaty interpretation. ${ }^{1410}$ They rarely conduct comprehensive analyses of foreign practice. ${ }^{1411}$

The sophistication of courts' approach varies from one substantive area of international law to the other. ${ }^{142}$ Japanese courts, for instance, are more diligent in the area of IHRL, ${ }^{1413}$ while Canadian courts are particularly careful with regard to issues of international tax law. ${ }^{1414}$ One possible reason for this uneven treatment is the domestic separation of powers, and the fact that in some domains, courts defer to the other branches. Moreover, cases in some substantive areas of international law are litigated by lawyers who are experts in domestic law, but not necessarily in international law (eg tax experts in cases involving DTAS). ${ }^{1415}$ The level of detail also likely hinges on the stakes of the case, and on its degree of complexity.

More generally, the case law is uneven. As Juliette McIntyre notes with regard to the Supreme Court of Canada and the High Court of Australia, " $[t]$ here are ebbs and flows'; ${ }^{1416}$ she shows that the case law of these two bodies 'is far from consistent, either internally or vis-à-vis each other'.1417

\subsubsection{Courts of States That Are Not Parties to the VCLT}

The practice of courts in States that have not ratified the VCLT ranges from an endorsement of the Convention's methods qua CIL to their utter neglect. This spectrum of attitudes even exists within the same jurisdiction. ${ }^{1418}$ In Israel and

1406 Rothwell (n 1387) 151; de Jonge (n 1387) 40 f; Aust, Rodiles, and Staubach (n 140) 94; Harris and Kakkaiyadi (n 1384) $114 \mathrm{ff}$.

1407 van Ert (n 1385) 176.

1408 Rothwell (n 1387) 152, footnote 155; van Ert (n 1385) 176.

1409 See van Ert (n 1385) 175 ff; Kretzmer (n 1383) 295 .

1410 van Ert (n 1385) 177, 18 o.

1411 See ibid 181.

1412 Eg Wall (n 1387) 184 f. See also Congyan (n 44) 277.

1413 Takashiba (n 1383) 227.

1414 van Ert (n 1385) 182.

1415 On tax lawyers' and international lawyers' divergent understandings of treaty interpretation, see Linderfalk (n 1381).

1416 McIntyre (n 72$) 64$.

1417 See ibid 63 .

1418 For a decision deemed 'unusually thorough for a us appellate court', see Ehrlich and Ehrlich v. American Airlines, Incorporated and Others, Appeal judgment, 36o F3d 366 
India, for instance, courts occasionally refer to the Convention's methods. ${ }^{1419}$ In Iran, the judicial practice is inconsistent. ${ }^{1420}$ Paradoxically, while Indian courts acknowledge that art. $31 \mathrm{ff}$ VCLT are customary, they do not seem to view them as obligatory. ${ }^{1421}$ In South Africa, the VCLT's methods are not explicitly endorsed. ${ }^{1422}$ References to them are rare, even if South African courts know of their existence and occasionally mention them. ${ }^{1423}$ In the United States, the lower courts (both state courts and federal courts) 'routinely' apply the VCLT's methods qua CIL, but the us Supreme Court is reluctant to do so. ${ }^{1424}$ Scholars have shown that the us practice has evolved together with the domestic legal and political context. ${ }^{1425}$ They have also highlighted an increasing deference of Us courts to the executive over time. ${ }^{1426}$ At the far end of the spectrum, in States such as Bangladesh, '[c]ourts do not apply the international rules of treaty interpretation and most judges are not aware of these rules.'.1427

As already noted for States that are parties to the VCLT (supra, 2.2.1), the practice of domestic courts is often uneven from one area of international law to another. In India, for instance, courts have almost exclusively referred to

(2d Cir 2004), No 02-9462, ILDC 2193 (US 2004), 8 March 2004, United States; Court of Appeals (2nd Circuit) [2 $\mathrm{d} \mathrm{Cir}$ ]. See however the predominantly purposive approach taken (on the basis of the VCLT) in Gandara v. Bennett and Others, Appeal judgment, $5_{2}^{28} \mathrm{~F}_{3} \mathrm{~d}$ 823 (11th Cir 2008), ILDC 2135 (US 2008), 22 May 2008, United States; Court of Appeals (1 1 th Circuit) [1 1 th Cir], the primarily textual approach taken in Yapp v. Attorney General, Appeal judgment, 26 F3d 1562 (11th Cir 1994), ILDC 2008 (US 1994), 3 August 1994, United States; Court of Appeals (11 th Circuit) [11 th Cir], or - according to the reporter the Court's premature recourse to the travaux contrary to the conditions stated in art. 32 vCLT in Wigleyv. Hares, Appeal judgment, 82 So.3d 932 (Fla. Dist. App. 2011), ILDC 1827 (US 2011), 27 July 2011, United States; Florida; 4th District (West Palm Beach); District Court of Appeal [Fla Dist App].

1419 Eg Kretzmer (n 1383) 295 ff; Kanwar (n 1383).

1420 Dizgovin (n 1383) 233.

1421 See Kanwar (n 1383) 244 .

1422 Dugard (n 36o) 464. The cases discussed by other authors do not suggest otherwise, see Du Plessis (n 1381); Johannes (n 1381).

1423 Tladi (n 1382) $145 \mathrm{ff}$.

1424 Criddle (n 1141) 434. See Ehrlich and Ehrlich v. American Airlines, Incorporated and Others, Appeal judgment, 36o F3d 366 (2d Cir 2004), No o2-9462, ILDC 2193 (US 2004), 8 March 2004, United States; Court of Appeals (2nd Circuit) [2d Cir]. See however Abel v. Minister of Justice of South Africa and Others, Initial application, Cr 5242/97, (2000) 4 All SA 63 (C), ILDC 286 (ZA 2000), 18 July 200o, South Africa; Western Cape High Court [WC-HC].

1425 Criddle (n 1141).

1426 Aust, Rodiles, and Staubach (n 140) 86 ff.

1427 Karim (n 1383) 105. 
(and followed) the methods of the VCLT when interpreting DTAs. ${ }^{1428}$ This suggests that the stakes of the case largely determine the diligence of domestic courts.

\subsubsection{Cross-Cutting Trends}

Regardless of whether States have ratified the VCLT or not, the case law of their courts displays some common features.

First, when courts do not refer to the VCLT's methods, their practice is sometimes in line with what the Convention requires, but not necessarily in every respect. Courts tend to prioritize some methods, while neglecting other aspects of this methodological frame. In India, for instance, courts sometimes rely on at least some of the Convention's methods. ${ }^{1429}$ However, they generally consider the broader circumstances of the conclusion of the treaty, as well as facts loosely connected to it, beyond what art. 32 VCLT permits. ${ }^{1430}$ Moreover, they sometimes refer to domestic legislative history, contrary to what art. 32 VCLT allows. ${ }^{1431}$ In Japan, courts tend to use the concepts and categories of domestic law, and domestic precedents. ${ }^{1432}$ They primarily engage in textual interpretation, sometimes to the exclusion of other methods, and without paying attention to the specificities of international lawmaking. ${ }^{1433}$ Still, their practice sometimes conforms to the VCLT, even when they do not explicitly mention the Convention. ${ }^{1434}$ In South Africa, the textual method is central as well, sometimes to the detriment of other methods, which are not demonstrably used. ${ }^{1435}$ South African courts occasionally use context, but far from systematically. ${ }^{1436}$ In Mexico and Colombia, courts rely on teleological considerations in order to justify what has been called an activist practice. ${ }^{1437}$

A second cross-cutting trend is that the case law is generally of uneven quality within the same jurisdiction (see 2.2.1 and 2.2.2, supra). As we will see, this heterogeneity can also be witnessed in the case of Switzerland (infra, sections 3 and 4$)$.

\footnotetext{
1428 Kanwar (n 1383) 254 ff. For a counterexample, see ibid 262.

1429 See Kanwar (n 1383) 244. Kanwar talks about Indian courts' use of 'similar principles of treaty interpretation'.

1430 See ibid 25 o.

1431 See ibid.

1432 Takashiba (n 1383) 229 ff.

1433 See ibid.

1434 See ibid $233 \mathrm{ff}$.

1435 Tladi (n 1382) $144 \mathrm{f}$.

1436 See ibid $151 \mathrm{f}$.

1437 Rodiles (n 1386).
} 
Third, as regards auxiliary means, which can be used in connection with all four interpretative methods, courts often consult materials stemming from their own jurisdiction to interpret treaties. Some judges are open to considering the decisions of foreign and international courts on treaty interpretation, ${ }^{1438}$ but they do not necessarily follow through. ${ }^{1439}$ Others are less willing to consider foreign and international materials. ${ }^{1440}$

Fourth, some courts are reluctant to apply treaties in the first place, often because domestic constitutional law constrains them. ${ }^{1441}$ Sergei Marochkin and Vladimir Popov report that Russian courts sometimes vaguely refer to 'international treaties' without specifying the agreements that are being considered. ${ }^{1442}$

To conclude, the domestic case law presents a number of difficulties from the perspective of its legality and of the quality of its reasoning. The uneven level of detail of the case law is particularly problematic from the angle of legality. It also jeopardizes the predictability, clarity, and consistency of judicial reasoning. As I will show, these difficulties largely overlap with those found in the Swiss practice (infra, 3.6).

\section{Swiss Courts and the Methods of Treaty Interpretation}

What approach do Swiss courts take to treaty interpretation? What can be said about the legality and quality of their interpretations?

To answer these questions, it seems apposite to break down the case law into three temporal stages. The first period includes rulings issued before 1980 . It pertains to the time during which the VCLT ('the treaty on treaties' $)^{1443}$ had not come into effect due to an insufficient number of ratifications (3.1). During

1438 Eg (especially regarding international rulings) van Ert (n 1385) $183 \mathrm{ff}$. See also Dugard (n 36o) 470; Tladi (n 1382) 145 f. For a consideration of the practice of other State parties, see Ehrlich and Ehrlich v. American Airlines, Incorporated and Others, Appeal judgment, 36o F3d 366 (2d Cir 2004), No o2-9462, ILDC 2193 (US 2004), 8 March 2004, United States; Court of Appeals (2nd Circuit) [2d Cir].

1439 Wigley v. Hares, Appeal judgment, ILDC 1827 (US 2011), 82 So.3d 932 (Fla. Dist. App. 2011), 27 July 201 1, United States; Florida; 4th District (West Palm Beach); District Court of Appeal [Fla Dist App].

1440 Sanzhuan (n 1381) 167.

1441 Marochkin and Popov (n 183) 226, 235 ff; Enabulele (n 1388) 330 ff; Congyan (n 44) 269, 330 ff; Sanzhuan (n 1381) 165; Orago (n 1382). See however Sanzhuan (n 1381) 166.

1442 See Marochkin and Popov (n 183) $232 \mathrm{f}$.

1443 Richard D Kearney and Robert E Dalton, 'The Treaty on Treaties' (1970) 64 American Journal of International Law 495. 
the second phase (1980-1990), the Convention was in force on the international plane, but had not yet been ratified by Switzerland (3.2). The third stage (1990-2016) begins with the Convention's entry into force in Switzerland, on 6 June 1990 (3.3).

After this survey of the practice, I analyze the parallels between the methods Swiss courts use to interpret treaties and written domestic laws, respectively (3.4). I also compare the practice of various Swiss courts among themselves (3.5), before studying the similarities and contrasts between the Swiss judicial practice and that of other domestic courts (3.6). Finally, I provide an overall evaluation of the practice (4).

The two first chronological stages in the Swiss practice (3.1 and 3.2) are studied based on the Swiss Federal Tribunal's case law. Other Swiss courts either did not exist at the time (which is the case for other federal courts), or do not offer online access to their case law for this period (which is the case for cantonal courts). The third period (3.3) includes the case law of the Swiss Federal Tribunal, but also that of other federal courts, selected cantonal courts, and military tribunals (Chapter 3, 4.1, supra). As regards the Swiss Federal Tribunal, the present chapter includes rulings published in the Court's official compendium (BGE), but also rulings outside this compendium, subject to their online availability (ie, dating from 2000 onwards). ${ }^{144}$

\section{The Swiss Federal Tribunal and Treaty Interpretation before the} VCLT's Entry into Force (1954-1980)

The Swiss Federal Tribunal already referred to the interpretative methods of the Vienna Convention before the Convention entered into force on the international plane, in $1980 .{ }^{1445}$ However, in this early period, the Court did not necessarily comply with all of the Convention's requirements, and it sometimes failed to provide compelling reasons for its interpretations. The case law hence displays occasional deficiencies in terms of both the legality and the quality of the Court's reasoning.

The Swiss Federal Tribunal cited art. ${ }_{31} \mathrm{f}$ VCLT as early as 1971, in a case pertaining to a treaty on railway transport concluded in 1858 between the Swiss Confederation, the canton of Schaffhausen, and the Grand Duchy of Baden. ${ }^{1446}$ The case is remarkable in light of the detailed justification offered by the Court,

\footnotetext{
$1444<$ www.bger.ch/index/juridiction/jurisdiction-inherit-template/jurisdiction-recht/ jurisdiction-recht-urteile20oo.htm>.

1445 The VCLT was ratified by Switzerland ten years later. It entered into force in Switzerland on 6 June 199 .

1446 BGE 97 I 359, at 3.
} 
its careful application of the various interpretative methods, and the richness of auxiliary means used. Yet the Court's approach differs, in some respects, from the methods prescribed by the Convention. Although the Court rejected the notion of 'clear meaning' and emphasized the treaty's object and purpose, it endorsed the 'primacy of the text', presumed to reflect the parties' common intentions. It considered that departing from the treaty's literal meaning was only justified if the context or the travaux demonstrated that the parties' intentions differed from the text. ${ }^{1447}$ While the Court relies on many methods of the VCLT, the weight given to the various methods is idiosyncratic.

Most decisions dating from this period do not mention the Vienna Convention, although many employ the methods prescribed by art. $31 \mathrm{f}$ VCLT. However, these methods, when they are used, are generally mentioned in passing, and not based on a predictable, clear, and consistent interpretative scheme, ${ }^{1448}$ which is detrimental to the quality of the Court's reasoning. Moreover, the case law is often riddled with references to domestic legal practices and other materials that are not mandated by the methods of treaty interpretation. In the landmark Frigerio decision of 1968, for instance, the Court noted that treaties needed to be interpreted if their text was 'not clear' or led to absurd results, and that the travaux were relevant if they provided clear evidence of the intentions of the contracting States. Relying on its own case law (as it often does in treaty interpretation), the Court added that treaties were bona fidei negotia to be interpreted pursuant to the reliance theory ('Vertrauenstheorie') of Swiss contract law. ${ }^{1449}$ The Court also relied on purposive and systematic interpretation, ${ }^{1450}$ and it mentioned the subsequent practice of the Swiss government and of German and Swiss shipping companies. ${ }^{1451}$ While the Court relies on the four methods of the Convention, it does so in response to the arguments raised by the Swiss government, rather than in application of clearly spelled out

1447 Ibid.

1448 BGE 101 Ib 16o (regarding the Swiss-US DTA of 1951); BGE 94 III 83 (regarding the treaty of 1869 on judicial jurisdiction ('Gerichtsstandsvertrag') between France and Switzerland); BGE 94 III 35 (on the Hague Convention of 1954 on Civil Procedure, and the establishment and consular agreement between Switzerland and Italy of 1868 and its Protocol of 1969); BGE 100 II 230, at 1 (regarding the 1892 Swiss-German treaty on the mutual protection of patents, design rights, and trademarks); BGE 89 I 115 (on the DTA of 1951 between Switzerland and the United States); BGE 101 Ia 533, at 5 b) (on the extradition treaty of 1900 between Switzerland and the United States); BGE 105 II 49, at 3 a) (on the Swiss-E Ec Free Trade Agreement).

1449 BGE 94 I 669, at 4. See also BGE 97 I 359, at 5.

145 O BGE 94 I 669, at 4 b).

1451 Ibid, at 5 . 
interpretative principles. The Court's reasoning with regard to the methods of treaty interpretation is not detailed, and it is based on Swiss legal concepts and practices. Moreover, the auxiliary means the Court relies on essentially consist of Swiss legal scholarship. The (primarily textual) reasoning of Frigerio was reiterated in a range of other cases predating the VCLT's entry into force. ${ }^{1452}$

What also emerges from the case law is that the Court rarely mentions all four interpretative methods, that the level of detail of its reasoning is uneven, and that the Court's approach frequently does not satisfy the virtues of predictability, clarity, and consistency. While the Swiss Federal Tribunal's reasoning is sometimes relatively thorough, ${ }^{1453}$ the devil is often in the details. Concerning historical interpretation, for example, the Court has noted that the negotiations leading to the conclusion of the treaty must be taken into account to the extent that they clearly reflect the intention of the contracting States. ${ }^{1454}$ Though the Court referred to written statements of the Swiss government addressed to Germany to interpret the Swiss-German Social Security Agreement of 1964, it did not mention Germany's practice, contrary to art. 32 VCLT. ${ }^{1455}$ Another difficulty is that the Court sometimes explicitly uses domestic legal concepts, categories, and practices, while neglecting international legal practice. In Dal-Bosco and Walther (1971), for instance, the Swiss Federal Tribunal invoked Frigerio when mentioning the principles of treaty interpretation 'applicable in Switzerland'.1456 The Court stated that Switzerland enjoys more interpretative freedom when interpreting domestic law than with regard to treaties. ${ }^{1457}$ Still, its approach suggests that when interpreting treaty law, it consults its own case law rather than international law.

At this early stage, one can already identify distinctive approaches taken by the Court to interpret treaties belonging to specific substantive areas of international law. The Court has for example refused to use Swiss constitutional law

1452 BGE $97 \mathrm{~V} \mathrm{35}$, at 3; BGE $105 \mathrm{~V} \mathrm{13}$, at 2 b); BGE $109 \mathrm{~V} \mathrm{224}$, at $3 \mathrm{~b}$ ); BGE $111 \mathrm{~V} \mathrm{117}$, at 1 b); BGE 113 V 98, at 2 b). Frigerio has also been cited in connection with the statement that a treaty is 'a closed structure of reciprocally negotiated concessions with an inner equilibrium', see BGE $97 \mathrm{~V} 35$, at 4 .

1453 Eg BGE 97 I 359, at 6 a), regarding a Treaty on Rail Transport concluded between the Swiss Confederation (respectively the canton of Schaffhausen) and the Grand Duchy of Baden and dating from 1858. In this case, the Court largely endorsed Vattel's famous maxim in claris non fit interpretatio, even if it acknowledged its limitations (see at 3 ). For a critique of this maxim, see Barradas de Freitas (n 127) $35 \mathrm{f}$.

1454 BGE 90 II 121 , at 2.

1455 BGE $97 \mathrm{~V} \mathrm{42}$, at 2.

1456 BGE 97 I 389 , at 13 .

1457 Ibid. 
to interpret the 1929 Swiss-German Convention on Enforcement ('Vollstreckungsabkommen'), ${ }^{1458}$ and it has stressed the importance of interpreting treaties independently from domestic legal concepts and categories in the context of the Swiss-EEC Free Trade Agreement. ${ }^{1459}$ In other cases, the Court is more willing to rely on domestic law.

It is worth noting that already in this early phase, the Swiss Federal Tribunal has applied principles of treaty interpretation to intercantonal agreements. ${ }^{1460}$ This case law, which was confirmed in several later cases (infra, 3.2), suggests that the Court considers these methods to apply to legal interpretation in general, and at least outside treaty interpretation (on this issue, see Chapter 6, supra).

\subsection{The Swiss Federal Tribunal and Treaty Interpretation after the VCLT's Entry into Force and before Its Ratification by Switzerland (1980-1990)}

The Swiss Federal Tribunal kept mentioning the methods of the VCLT after the Convention had entered into force for its State parties in 1980, and before it came into effect in Switzerland in June 1990. ${ }^{1461}$ However, during this period as well, the Court's use of interpretative methods frequently lacked predictability, clarity, and consistency.

During this second phase, the Court's confident, explicit endorsement of the VCLT's methods - despite Switzerland not being a party to the Convention at the time - is noteworthy. In some decisions, the Court did not even clarify that Switzerland had not ratified the VCLT, or whether the methods of the Convention reflected CIL. ${ }^{1462} \mathrm{~A}$ decision of 1986 provides an explanation for this approach. In this case, the Court noted that Switzerland had not ratified the VCLT because it disagreed with its provisions on dispute settlement, though it approved of its other provisions. The Court concluded that VCLT provisions reflecting CIL could be applied by Swiss courts. ${ }^{1463}$

Many rulings dating from 1980 to 1990 do not mention the Convention, in continuity with Frigerio. While the Court, in most of these cases, uses many of the VCLT's methods, it does not adopt a predictable, clear, and consistent

\footnotetext{
1458 BGE 98 Ia 314 , at 1.

1459 BGE 105 II 49, at 3 a).

146о BGE 96 I 636, at 4 c); BGE 100 Ia 418 , at 5 .

1461 BGE 112 V 337; BGE 1 O9 Ia 217, at 4 b) bb).

1462 BGE $110 \mathrm{Ib} 287$, at 4 (on the Swiss-Dutch DTA).

1463 BGE 112 Ia 75 , at 4 b).
} 
interpretative approach. ${ }^{1464}$ Only a handful of decisions are of higher quality, such as a particularly detailed ruling dating from 1987 pertaining to the Warsaw Convention, ${ }^{1465}$ or a decision of 1988 concerning the treaty on judicial jurisdiction ('Gerichtsstandsvertrag') between France and Switzerland. ${ }^{1466}$ It is worth noting that in line with its earlier case law (supra, 3.1), the Swiss Federal Tribunal has applied principles of treaty interpretation to intercantonal agreements. ${ }^{1467}$

\subsection{Swiss Courts and Treaty Interpretation after the VCLT's Entry into Force in Switzerland (1990-2016)}

Contrary to the previous sections (supra, 3.1 and 3.2 ), which exclusively concerned the Swiss Federal Tribunal, the present section also includes the case law of other Swiss courts. ${ }^{1468}$ Scope precludes analyzing the entire case law of the MCC available online and dating from 1915 onwards. ${ }^{1469}$ Only decisions of the MCC dating from 2006 and later published on the website of the Swiss authorities have been taken into account. ${ }^{1470}$

\subsubsection{The Swiss Federal Tribunal \\ 3.3.1.1 The Court's Interpretative Approach in General}

Since 1990, the Court has been adopting a more predictable, clear, and consistent approach to treaty interpretation and its methods. Several decisions are even remarkably detailed and thorough. ${ }^{1471}$ However, some difficulties remain with regard to both the legality and the quality of the Court's reasoning.

One characteristic of this practice is the Court's explicit endorsement of the VCLT's methods as a reflection of CIL. The Court has noted that these methods

\footnotetext{
1464 BGE 113 Ib 276 (on the European Convention on Extradition); BGE 112 V 16 (on the social security agreement of 1969 between Turkey and Switzerland); BGE 110 V 72 (pertaining to several bilateral social security agreements).

1465 BGE 113 II 359.

1466 BGE 114 II 265 , at 3 .

1467 BGE 112 Ia 75, at 4; BGE 110 Ia 123, at 1. See also (on the more general applicability of international law to intercantonal agreements) BGE $106 \mathrm{Ib}$ 154, at 3.

1468 This is due to the fact that this case law is accessible online for these more recent years (which applies to cantonal courts), or that these courts have been established after 1990 (this concerns federal courts other than the Swiss Federal Tribunal).

1469 <eu.alma.exlibrisgroup.com/view/delivery/41BIG_INST/12329504630001791\# main-carousel $>$.

$1470<$ <ww.oa.admin.ch/de/entscheidungen-militaerjustiz.html >.

1471 Eg BGer, judgment 4A_65/2018 of 11 December 2018; BGE 144 III 559.
} 
already applied qua CIL before being codified. ${ }^{1472}$ According to the Court, they also govern treaties ratified by Switzerland before the adoption of the VCLT. ${ }^{1473}$ The Court is sometimes more cautious in its formulations, eg when it considers that the VCLT is 'essentially' a codification of CIL. ${ }^{1474}$ It is worth noting that the Court also applies the methods of the VCLT to treaties concluded between Switzerland and subjects of international law other than States, eg the UN, the ILO, and the WIPO. ${ }^{1475}$ It has even applied them to the Swiss-Persian Treaty of Establishment of $1934 .{ }^{1476}$ This could suggest that the Court considers that the VCLT's methods were already customary at that time. The Swiss Federal Tribunal uses the Convention's methods as legally binding guides. In (rare) cases, it has sought to demonstrate that a case had (or had not) ${ }^{1477}$ been decided in conformity with the VCLT. ${ }^{1478}$

The Swiss Federal Tribunal has acknowledged that the VCLT's entry into force requires making some adjustments to the Swiss case law on treaty interpretation. One main change is that courts must ascertain the 'international' meaning of social security agreements, instead of applying concepts of Swiss social security law by analogy. ${ }^{1479}$ Yet this alleged change does not follow from a fundamental difference between the interpretative methods of domestic and international law. Rather, it is a corollary of the idiosyncratic features of international lawmaking (on this issue, see supra, Chapter 5, 3.3). As a matter of fact, the Swiss Federal Tribunal has stated that the methods of the Vienna Convention are 'relatively similar to the interpretative methods that apply to general and abstract rules in domestic law'.1480 It has also asserted that these

1472 BGE 138 II 524, at 3.1. See also BGE 141 II 447, at 4.3.1; BGer, judgment 4P.114/2006 of 7 September 2006, at 5.4.1.

1473 BGE 122 II 234, at 4 c). Examples include the Swiss-Danish DTA of 1974 (BGer, judgment 2A.239/2005 of 28 November 2005, at 3.4.1), the Free Trade Agreement between Switzerland and the EEC of 1972 (BGer, judgment 2C_907/2013 of 25 March 2014, at 2.2.7), the Convention on the Contract for the International Carriage of Goods by Road, which came into effect in Switzerland in 1970 (BGE 138 III 708, at 3.1), and the 1955 Swiss-Italian Agreement on Border and Field Traffic (BGE 138 II 524, at 3 ).

1474 BGE 122 II 234, at 4 c); BGer, judgment 4P.114/2006 of 7 September 2006, at 5.4.1.

1475 BGer, judgment 2P.36/2004 of 9 May 2005, at 5.6.

1476 BGer, judgment 5A_197/2007 of 31 August 2007, at $3.1 \mathrm{ff}$.

1477 BGer, judgment 2A.46o/1999 of 26 April 200o, at 3 b) cc) (although the Court itself mistakenly refers to the domestic travaux).

1478 BGer, judgment 9C_6o2/2015 of 7 January 2016, at 3.4 .

1479 Compare BGE 124 V 225, at 3 а), BGE 117 V 268, at 3 b), or BGE 119 V 98, at 6 a), with BGE $111 \mathrm{~V} \mathrm{117}$, at $1 \mathrm{~b}) ;$ BGE $112 \mathrm{~V} \mathrm{145}$, at $2 \mathrm{a}$ ).

1480 BGE 136 I 290, at 2.3.2. The continuity between domestic and international methods in the Swiss judicial practice is addressed in more detail in subsection 3.4 (infra). 
methods match its own previous approach to treaty interpretation, ${ }^{1481}$ which glosses over the fact that this earlier practice was, in most cases, unpredictable, unclear, and inconsistent in terms of the methods used (supra, 3.1 and 3.2). Moreover, as the present study shows, even more recent cases are not devoid of inconsistencies.

When it does refer to the interpretative methods of treaty law codified in the VCLT, the Swiss Federal Tribunal applies them to a wide range of treaties. The Court regularly notes that the Swiss-EU Agreement on the Free Movement of Persons must be interpreted pursuant to the VCLT, ${ }^{1482}$ at least to the extent that its provisions do not contain concepts of EU law. ${ }^{1483}$ The Court has also relied on the VCLT to justify the need to interpret the Swiss-EU Agreement independently from domestic law. Paradoxically, based on this argument, the Court closely follows the case law of the CJEU. ${ }^{1484}$ While scope precludes addressing this issue in more detail, it is important to stress that for CJEU case law predating the signature of the Agreement, adherence to the CJEU's rulings is commanded neither by the vCLT nor by the Agreement. ${ }^{1485}$ In some decisions pertaining to the Swiss-EU Agreement ${ }^{1486}$ and to other treaties between Switzerland and the EU, ${ }^{1487}$ the Court has not referred to the vCLT. These omissions are further indications that the Court's interpretative method is guided by EU law, and not by international law.

The Court has applied the VCLT's methods to the ECHR, while stressing that its characteristics as an international human rights treaty and as a living instrument' must influence its interpretation. ${ }^{1488}$ It also uses the VCLT to interpret other treaties, including the Lugano Convention, ${ }^{1489}$ the Aarhus Convention, ${ }^{1490}$ the Swiss-US DTA ${ }^{1491}$ and other DTA s, ${ }^{1492}$ the Headquarters

1481 BGE 122 II 234, at 4 C); BGer, judgment 4P.114/2006 of 7 September 2006, at 5.4.1.

1482 BGE $132 \mathrm{~V} 423$, at 9.5.1; BGE $135 \mathrm{~V} 339$, at 5.3; BGE $138 \mathrm{~V} 258$, at 5.3; BGE 139 II 393, at 4.1.1; BGE 142 II 35, at 3.2; BGer, judgment 2C_301/2016 of 19 July 2017 , at 2.2 .

1483 BGE 14 O II 167 , at 5.5.2.

1484 BGE 142 II 35, at 3.2. See also BGE $132 \mathrm{~V} 423$, at 9.1, 9.2 and 9.5; BGE 136 II 65, at 3.1.

1485 Art. 16(2) of the Swiss-EU Agreement. On this issue, see Besson and Ammann (n 97). For a different view, see Benedikt Pirker, 'Zu den für die Auslegung der Bilateralen Abkommen massgeblichen Grundsätzen: Gedanken zu BGE 140 II 112 (Gerichtsdolmetscher)' (2015) 116 Schweizerisches Zentralblatt für Staats- und Verwaltungsrecht 295.

1486 BGE 140 II 460 , at 4.1 ; BGE 136 II 5 , at 3.4 .

1487 BGE 138 II 536 (on the Swiss-EU Agreement on the Taxation of Savings Income).

1488 вGE 139 I 16, at 5.2.2. See also BGE 137 I 284, at 2.1.

1489 BGE 131 III 76 , at 3.2; BGE 131 III 227 , at 3.1 .

149 O BGE 141 II 233 , at $4 \cdot 3 \cdot 3$.

1491 BGE 139 II 4O4, at 7.2.1.

1492 Eg вGE 143 II 136, at 5.2 (regarding the Swiss-Dutch DTA). 
Agreement between the Swiss Federal Council and the Bank for International Settlements, and a related exchange of letters, ${ }^{1493}$ the New York Convention on the Recognition and Enforcement of Foreign Arbitral Awards, ${ }^{1494}$ and the Energy Charter Treaty. ${ }^{1495}$

While the Court's recent interpretative approach is - at least as a matter of principle - more predictable, clear, and consistent, it also displays signs of repetitiveness and superficial engagement with the various interpretative methods. Moreover, the fact that the VCLT's methods are acknowledged as customary and that they are mentioned as the starting point of interpretation does not mean that they are followed in practice.

Art. 31(1) VCLT is the most frequently quoted provision of the VCLT in the Swiss case law. The Court often neglects the fact that the 'general rule' of art. 31 is not limited to its first paragraph. ${ }^{1496}$ While in rare cases, the Court cites art. $3_{1} \mathrm{f}$ VCLT integrally, ${ }^{1497}$ this does not detract it from focusing on its preferred $\operatorname{method}(\mathrm{s})$ and from neglecting others. ${ }^{1498}$ This is a fortiori the case when the Court merely cites art. 31(1) VCLT at the beginning of the interpretative process. ${ }^{1499}$ When interpreting the Swiss-Persian Establishment Treaty of 1934, for instance, the Court has emphasized the purposive method. ${ }^{1500}$ In another decision on the Swiss-Portuguese Social Security Convention of 1975, the Court stated that it had no reason to depart from the ordinary and clear meaning of the treaty. ${ }^{1501}$ Occasionally, however, the Court has applied the different methods of the VCLT in a more predictable, clear, and consistent way, ${ }^{1502}$ going beyond art. 31(1) VCLT to mention its paragraphs 2 and $3 \cdot{ }^{1503}$

\footnotetext{
1493 BGE 140 V 385 , at 4.2 .

1494 BGE 138 III 520 , at $5 \cdot 4$.

1495 BGE 141 III 495, at 3.5.1.

1496 Ibid (Energy Charter Treaty); BGE 139 II 393, at 4.1.1 (Swiss-EU Agreement on the Free Movement of Persons); BGE 131 III 76, at 3.3 (Lugano Convention); BGE 122 II 234, at 4 c) (Agreement between Switzerland and the Federal Republic of Germany on the Road between Lörrach and Weil am Rhein on Swiss Territory). See also BGer, judgment 6B_274/2009 of 16 February 2010, at 3.1.2.1 (UN Convention Against Torture).

1497 BGE 138 II 524, at 3.1 (Convention between Switzerland and Italy on border and field traffic); BGE 132 V 423, at 9.5.1 (Swiss-EU Agreement on the Free Movement of Persons); BGE 139 II 404, at 7.2.1 (interpretation of the Swiss-US DTA).

1498 вGE 138 II 524, at 4.3 (focus on object and purpose); BGer, judgment 4A_736/2011 of 11 April 2012, at 3.3 (focus on object and purpose).

1499 BGer, judgment 5A_467/2014 of 18 December 2014, at 2.3.

1500 BGer, judgment 5A_197/2007 of 31 August 2007, at $3.1 \mathrm{ff}$.

1501 BGer (Swiss Federal Insurance Court), judgment I 99/o3 of 17 November 2003, at 3.2.

1502 BGer, judgment 2C_436/2011 of 13 December 2011, at 3.3 ff; BGer, judgment 2C_498/ 2013 of 29 April 2014, at $5.1 \mathrm{ff}$ (although the Court uses, inter alia, the domestic travaux). 1503 BGer, judgment 2C_9/2016 of 22 August 2016, at 2.2 (regarding art. 31(2)(b) VCLT).
} 
Some trends noticed for the Court's earlier case law (supra, 3.1 and 3.2) are still present in this recent practice. One such tendency is self-referentiality. In many rulings, the Court has relied on the Swiss practice to interpret treaties, including the practice of the Swiss authorities pertaining to the ratification of a treaty. It especially relies on the dispatch of the Federal Council, ie, the official statement issued by the federal government before the domestic parliamentary approval of a treaty. ${ }^{1504}$ Yet the Court seems biased, in the sense that it only highlights the Swiss practice, but not that of Switzerland's treaty partners. It has for example rejected the invocation of foreign (French) legislative materials by one of the parties to a dispute. ${ }^{1505}$ The Court also frequently relies on auxiliary means to interpret treaties. It especially uses scholarly writings and, more rarely, foreign and international judicial decisions. ${ }^{1506}$ Only Swiss judicial decisions are often cited. ${ }^{1507}$

Overall, references to the VCLT's methods are more frequent in recent decades. However, the Swiss Federal Tribunal has far from systematically referred to the Vienna Convention in the context of treaty interpretation, which can be problematic from the perspective of the legality and quality of its rulings.

Some decisions that do not mention the VCLT explicitly point to some of the Convention's methods. In a case of 2016, the Court stressed the importance of interpreting the Lugano Convention independently from domestic law. ${ }^{1508}$ While the Court did not refer to the VCLT, it stated that the four 'customary interpretative methods' had to been relied on, before applying them to the case at hand. ${ }^{1509}$ In an earlier decision dating from 1997, the Court mentioned that the Lugano Convention had to be interpreted based on the 'classic interpretative criteria' (by which it supposedly meant the customary methods codified in the VCLT), while also accounting for 'the characteristics of a unified international legal order'.1510

1504 BGer, judgment 6B_274/2009 of 16 February 2010, at 3.1.2.1; BGer, judgment 2A.460/ 1999 of 26 April 200o, at 3 b) cc); BGer, judgment 2A.26o/2000 of 21 November 200o, at $3 \mathrm{~g})$; BGer, judgment $2 \mathrm{C} \_498 / 2013$ of 29 April 2014, at $5.1 \mathrm{ff}$.

1505 BGer, judgment 4A_616/2015 of 20 September 2016, at 3.2.2.

1506 BGer, judgment 6B_274/2009 of 16 February 2010, at 3.1.2.1.

1507 BGer, judgment $2 C_{-} 75^{2} / 2014$ of 27 November 2015 , at 3.3.2 (the Court also mentions the practice of the States parties to another DTA than the one at stake); BGE 144 III 368 , at 3 (regarding the Hague Convention of 2 October 1973 on the Law Applicable to Maintenance Obligations).

1508 BGE 142 III 420, at 2.3.1. See also BGE 142 III 466, at 4.2.1 and 6.1.2; BGE 135 III 185, at 3.4.1.

1509 BGE 142 III 42O, at 2.3.1. See also at 2.3.2.

1510 BGE 123 III 414 , at 4. 
Other decisions that do not mention the Vienna Convention are less clearly in line with the Convention's methods. This is particularly problematic from the perspective of the legality of the Court's reasoning. In a decision of 1999, for instance, the Court had to interpret the Swiss-German Social Security Agreement of 1964. It did not use the vCLT but, instead, its own (primarily textual) case law on treaty interpretation, ${ }^{1511}$ as it did in other decisions pertaining to social security agreements. ${ }^{1512}$ Whether it failed to mention the VCLT because these agreements all predated the Vienna Convention's entry into force in Switzerland in 1990 is unclear. The primacy of the text was also applied to other treaties. ${ }^{1513}$

Another problematic tendency from the perspective of the Court's methods and the quality of its reasoning is that the VCLT is hardly ever mentioned in some interpretative contexts. The Court has not cited the VCLT with regard to the two UN Covenants. ${ }^{1514}$ It has rarely used it when interpreting host State agreements, ${ }^{1515}$ or treaties concluded under the auspices of the Council of Europe. ${ }^{1516}$ It has also failed to mention it when interpreting the Government Procurement Agreement of the WTO. ${ }^{1517}$ In a judgment of 2018 pertaining to the Hague Convention on the Civil Aspects of International Child Abduction, the Court cited a block of text on interpretative methods which it regularly uses in relation to the interpretation of domestic law, without referring to the VCLT. ${ }^{1518}$

The Court adopts distinctive approaches with regard to specific treaties, which reinforces this impression of path dependence. In connection with the Convention on the Contract for the International Carriage of Goods by Road, ${ }^{1519}$ the TRIPS Agreement, ${ }^{1520}$ the Hague Convention on the Protection of Minors, ${ }^{1521}$ or the Lugano Convention,, ${ }^{1522}$ the Court has stressed the

\footnotetext{
1511 BGE 125 V 503, at 4 b).

1512 BGE $140 \mathrm{~V} 476$, at 3.3.1; BGE $124 \mathrm{~V} \mathrm{145}$, at 3 a); BGE 122 V 381, at 5 .

1513 Examples include the Patent Cooperation Treaty between Switzerland and Liechtenstein (BGE 127 III 461, at 3 b), where the Tribunal applied its approach developed in the Baden Railway Transport Case, supra, 3.1), the European Patent Convention (BGE 117 II 480, at 2 b)), and the Lugano Convention (BGE 121 III 336, at 5 c)).

1514 BGE 126 I 240 , at $2 \mathrm{~g}$ ) (on the ICESCR).

1515 BGE 136 III 379 (no mention of the VCLT); see however BGE $140 \mathrm{~V} 385$, at 4.2.

1516 BGE 133 II 136, at 5.2.1 (regarding the European Convention on Transfrontier Television); BGE 141 IV 108 (an otherwise remarkably detailed judgment regarding the Council of Europe's Convention on Cybercrime).

1517 BGE 142 II 369 , at 3 .

1518 BGer, judgment 5 A_576/2018 of 31 July 2018 , at 4.3.2.

1519 BGE 138 III 708 , at 3.4.

1520 BGE 13 O III 267 , at 4.1.

1521 BGE 138 III 11, at 5.1.

1522 BGE 129 III 626, at 5.2.1; BGE 124 III 436, at 2 c).
} 
importance of limiting hermeneutic divergence and of fostering uniform interpretation. With regard to specific treaties, such as DTAs, the Court frequently stresses States' duty to interpret treaties in good faith, and to avoid absurd or abusive interpretations. ${ }^{1523}$

Even relatively recent decisions do not mention the methods of the VCLT, at least not all of them, and not in a predictable, clear, and consistent way. ${ }^{1524}$ Instead of using the VCLT, the Court - as previously emphasized - tends to rely on its own case law on treaty interpretation. ${ }^{1525}$ This confirms the risk of circularity that exists when domestic courts interpret international law. ${ }^{1526}$ A cluster of examples is provided by cases on the Lugano Convention, in which the Court refers to its own practice of following the CJEU's case law. ${ }^{1527}$ The level of detail of the Court's reasoning is uneven. This may reflect an unpredictable, unclear, and inconsistent approach. Of course, it may also be due to the fact that some cases do not raise difficult interpretative issues.

While the majority of the Court's decisions issued after the Convention's entry into force in Switzerland do not mention the VCLT, some decisions, in addition to citing the Convention's methods, are particularly detailed and carefully justified. ${ }^{1528}$ Moreover, the Court was already referring to the vCLT's methods within a few days of the Convention coming into effect in Switzerland. ${ }^{1529}$

\subsubsection{The Court's Use of the Four Interpretative Methods}

The richness of the Court's case law makes it possible to analyze its use of the four interpretative methods (supra, Chapter 6, section 2).

In the Court's practice, the text often limits the reach of other interpretative arguments. The presumption it establishes regarding the meaning of the treaty cannot be easily rebutted. ${ }^{1530}$ Occasionally, the Court uses language dictionaries to ascertain the treaty text, ${ }^{1531}$ and sometimes specialized

\footnotetext{
1523 BGer, judgment 2A.416/2005 of 4 April 2006, at 3.1; BGE 143 II 136.

1524 BGE 135 III 574, at 3; BGE 140 II 305 .

1525 BGE $140 \mathrm{~V} 493$, at 3 .

$15^{26}$ On this issue, see Besson and Ammann (n 6o) $125 \mathrm{ff}$.

1527 BGE 141 III 382 , at $3 \cdot 3$.

1528 BGE 119 V 98, and more recently: BGE 141 II 233; BGer, judgment 4A_736/2011 of 11 April 2012, at 3.3; BGer, judgments 2C_64/2013 and 2C_65/2013 of 26 September 2014, at $3.3 \cdot 3 \mathrm{ff}$.

1529 BGE 116 IV 262, at b) cc), issued on 14 June 1990, eight days after the VCLT's entry into force in Switzerland.

1530 BGE 134 III 555 , at $2.4 \mathrm{ff}$.

1531 BGE 122 V 381, at 5 b) (Le Grand Robert); BGer, judgment 2P.36/2004 of 9 May 2005, at 6.1 (Le Nouveau Petit Robert).
} 
dictionaries. ${ }^{1532}$ It regularly relies on the notion of 'clear text', ${ }^{1533}$ which is consistent with its earlier case law (eg supra, 3.1) and its approach to domestic law. ${ }^{1534}$ This notion expresses the fact that the Court has no doubt (or considers that it has no margin of appreciation) regarding the meaning of a legal norm. Yet as is well-known, clarity is the result of an evaluative judgment. Moreover, clarity (from the interpreter's perspective) does not rule out the need for interpretation (eg to explain the meaning of the law to others). ${ }^{1535}$ The notion of 'clear text' must hence be used with parsimony, and it must be carefully justified.

The context is sometimes decisive in the Swiss Federal Tribunal's practice, especially when the Court prioritizes interpretative coherence (or even uniformity) or constancy (ie, hermeneutic continuity over time). In a case of 1996 pertaining to the Swiss-Yugoslav Social Security Agreement, for instance, the Court has, without citing the VCLT, given weight to systematic interpretation and to 'the interest in a coherent interpretation of the international treaty'. ${ }^{1536}$ As previously mentioned, the Court rarely goes beyond citing the first paragraph of art. 31 VCLT. Still, it has occasionally referred to art. 31(2) VCLT, which defines the notion of context, ${ }^{1537}$ and especially to art. 31(3) VCLT, which pertains to subsequent agreements, subsequent practice, and systemic integration. ${ }^{1538}$ This last paragraph has been cited by the Court to emphasize the relevance of other treaties ${ }^{1539}$ and of foreign judicial practice. ${ }^{1540}$ The Court has also noted that art. 31(3)(a) vCLT can be used to reach a level of interpretative uniformity. ${ }^{1541}$ The Court has also referred to the parties' subsequent treaty practice without expressly mentioning the VCLT. ${ }^{1542}$ In many cases, however, subsequent agreements and subsequent practice are not prominent in the Court's case law.

\footnotetext{
1532 See the Abacha case, in which the Court referred to Black's Law Dictionary, to Dahl's Law Dictionary, and to the Navarre Economic and Legal Dictionary: BGE 129 II 268, at 3.4.1.

1533 BGE 135 II 243 , at 3.2.

1534 See recently BGE 140 II 202, at 5.1.

1535 On this point, see Barradas de Freitas (n 127) $35 \mathrm{f}$.

1536 BGE 122 V 381 , at 5 b).

1537 BGE 13 O III 43 O, at 3.5 .

1538 Eg BGE 141 II 233, at 4.3.4 (art. 31(3)(a) and (b) VCLT); BGE 123 I 112, at 4 d) cc) (art. $31(3)$ (b) and (c) VCLT).

1539 Eg BGE 131 III 227, at 3.1; BGE 128 II 305, at 3.1.

1540 BGE 138 III 708, at 3.1.

1541 BGE 130 III 267 , at 4.1.

1542 Eg BGE 129 II 114, at 4.2 f; BGE 132 II 65, at 2.3 .
} 
Purposive interpretation often occupies a central place in the Court's reasoning. Among the methods prescribed by art. $31 \mathrm{f} \mathrm{VCLT,} \mathrm{the} \mathrm{Court} \mathrm{fre-}$ quently emphasizes the treaty's object and purpose. ${ }^{1543}$ It does so to interpret the Swiss-EU Agreement on the Free Movement of Persons, the purpose of which, according to the Swiss Federal Tribunal, is to ensure free movement 'based on the provisions in force within the European Union', and hence to guarantee an interpretation of the Agreement that is 'parallel' to the law of the EU. ${ }^{1544}$ Yet given the difficulty of ascertaining the object and purpose of a treaty, and in light of art. 16(2) of the Agreement, the Court's approach is problematic. ${ }^{1545}$ Teleology also played a crucial role in a high-profile case decided in 2018, which involved Russia and several Ukrainian companies, and which was linked to Russia's annexation of the Crimean peninsula. ${ }^{1546}$ Another interesting example is a case on the New York Arbitration Convention, in which the Swiss Federal Tribunal mentioned that because the purpose of the Convention is to ensure the recognition and enforcement of foreign arbitral awards, judges must interpret this treaty in a way that is 'pragmatic, flexible, and not formalistic'.1547 Yet to equal purposive interpretation with result-oriented reasoning is misguided and neglects the constraining effect of teleology.

The Swiss Federal Tribunal seldom refers to historical interpretation in the context of treaty interpretation. In line with its emphasis on the text, the Court has stated that the travaux can only be used to interpret a treaty beyond its wording if the text does not reflect the parties' intentions. ${ }^{1548}$ When it does engage in historical interpretation, the Court, as previously mentioned, frequently refers to the practice of the Swiss authorities pertaining to the ratification of a treaty, especially to the Federal Council's dispatch. ${ }^{1549}$ This approach is at odds with what art. 32 VCLT permits.

\footnotetext{
1543 BGE 122 II 234, at 4 d); BGE 138 II 524, at 3.1 and 4.3; BGer, judgment 4A_736/2011 of 11 April 2012, at 3.3.3.

1544 Eg BGE 140 II 364 , at $5 \cdot 3$.

1545 On this issue, see Besson and Ammann (n 97). See also Ammann, 'La non-discrimination, principe charnière d'interprétation : l'exemple de l'art. 2 ALCP' (n 1369).

1546 BGE 144 III 559, at 4.4.5.

1547 BGE 138 III 520 , at $5 \cdot 4 \cdot 3$.

1548 BGE $135 \mathrm{~V} 339$, at $5 \cdot 3$.

1549 Eg BGE 141 II 233, at 4.3.1; BGE 136 II 241, at 14.2, BGE 133 V 367, at 9.1, and BGE 131 V 390, at 10.1.
} 


\subsubsection{Other Federal Courts}

\subsubsection{The Swiss Federal Administrative Court}

While the case law of the Swiss Federal Administrative Court (SFAC) is only available from 2007 onwards, it provides interesting insights into the methods of treaty interpretation. The SFAC's practice is often more detailed and comprehensive than the Swiss Federal Tribunal's, especially when the Court interprets DTAs and the so-called 2009 'UBS Agreement'1550 between Switzerland and the United States.

Given the short timeframe over which this case law spans, a chronological categorization is unwarranted. Instead, the rulings can be classified based on whether they do or do not mention the interpretative methods of the VCLT.

A number of decisions of the SFAC do not mention the VCLT, are not based on a predictable, clear, and consistent interpretative scheme, and invoke previous judicial decisions on treaty interpretation. One example is a case of 2010 pertaining to a treaty concluded in 1974 between Switzerland and Spain on the protection of indications of source, appellations of origin, and similar appellations. ${ }^{1551}$ In this case, the Court mentioned several interpretative methods, including context and teleology, ${ }^{1552}$ albeit not in a systematic way. The Court almost exclusively referred to the Swiss Federal Tribunal's case law on the issue (including to cases dealing with the interpretation of other, similar agreements), ${ }^{1553}$ in addition to citing its own previous decisions and cantonal cases. ${ }^{1554}$

Another case in which the Court did not refer to the VCLT pertained to UBS and a us request for administrative assistance in the framework of the SwissUS DTA. ${ }^{1555}$ In this case, the Court referred to the text, context, and teleology, again not in a predictable, clear, and consistent way. It also relied on Swiss case law. ${ }^{1556}$

Some cases that do not mention the VCLT are even more clearly at odds with what the Convention and/or high-quality judicial reasoning require. In a

\footnotetext{
$155^{\circ}$ Agreement Between the United States and the Swiss Confederation on the Request for Information From the Internal Revenue Service of the United States Regarding U BS AG, a Corporation Established Under the Laws of the Swiss Confederation, available in English at <www.irs.gov/pub/irs-drop/us-swiss_government_agreement.pdf $>$.

1551 SFAC, judgment B-30/2009 of 8 April 2010. See also judgment B-1295/2015 of 22 August 2016.

1552 SFAC, judgment B-30/2009 of 8 April 2010, at 3.8.

1553 Ibid, at 3.5.

1554 Ibid, at 5.2.

1555 SFAC, judgments A-7342/2008 and A-7426/2008 of 5 March 2009, at 2.

1556 Ibid, at $4.4 \mathrm{f}, 5.3 \mathrm{f}$.
} 
case pertaining to the Aarhus Convention, for instance, the SFAC (contrary to what art. 32 VCLT allows) relied on the practice of the Swiss authorities concerning the ratification of a treaty. ${ }^{1557}$ Paradoxically, it did so right before acknowledging that treaties must be interpreted independently from domestic law. ${ }^{1558}$ Similarly, in a ruling pertaining to the 2012 Swiss-Austrian treaty on cooperation in tax matters and financial markets, the Court mentioned textual, systematic, and purposive interpretation, as well as the practice of the Swiss authorities concerning the ratification of a treaty, ${ }^{1559}$ again contrary to what art. 32 VCLT permits (on this issue, see also infra). Some rulings merely cite the case law of the Swiss Federal Tribunal on treaty interpretation. ${ }^{1560}$ In other cases, the Court refers to its own case law on the issue and to the primacy of the text. ${ }^{1561}$ It is worth noting that in some cases that do not refer to the VCLT, the Court has mentioned the principle of auto-interpretation, which rarely appears in the Swiss practice. ${ }^{1562}$

In contrast with the case law of the Swiss Federal Tribunal, a great number of rulings of the SFAC mention art. $31 \mathrm{f} \mathrm{VCLT}$ and describe their content (including art. $31(2)$ and (3) VCLT). ${ }^{1563}$ The vast majority of these rulings refer to the UBS Agreement and to DTAs.

The Court often notes that the VCLT codifies the customary methods of treaty interpretation, ${ }^{1564}$ and it has even stated that these methods are 'inherent in every legal order' ${ }^{\prime 565}$ Hence, according to the Court, the VCLT's methods apply to (and can be applied by) ${ }^{1566}$ States that have not (yet) ratified

\footnotetext{
1557 SFAC, judgment A-4186/2015 of 28 January 2016, at 7-5.3.1.

1558 Ibid, at 7.5.4.1.

1559 SFAC, judgment A-7010/2015 of 19 May 2016, at $5.1 \mathrm{ff}$.

1560 SFAC, judgment B-1217/2012 of 5 September 2012, at 5.1.1.

1561 SFAC, judgment A-2744/2008 of 23 March 2010, at 3.9, with reference to judgment A-7789/2009 of 21 January 2010.

1562 SFAC, judgment C-2205/2008 of 26 May 2010, at $5 \cdot 5$ (on the Social Security Agreement of 1984 between Switzerland and Israel).

${ }_{1563}$ The SFAC's official website makes it convenient to search for rulings citing art. $31 \mathrm{f} \mathrm{VCLT}$ (in addition to the fact that such rulings are easier to locate than those that do not mention art. $31 \mathrm{f} \mathrm{VCLT}$ ). The website includes an index of the legal provisions cited in the Court's rulings. Contrary to what applies to the case law of the Swiss Federal Tribunal, this index is available for the Court's entire case law (<www.bvger.ch/publiws/pub/index.jsf $>$ ).

1564 SFAC, judgment A-7789/2009 of 21 January 2010, at 3.5; SFAC, judgment A-7663/2010 of 28 April 2011 (regarding the methods of art. 31 VCLT); SFAC, judgment A-6633/2010 of 6 June 2011, at 2.2 and 4.2.3 (regarding the interpretative methods of the VCLT in general).

1565 SFAC, judgment A-6159/2010 of 10 February 2011, at 3.4.

1566 SFAC, judgment A-7789/2009 of 21 January 2010, at 3.6.1 (with reference to the French practice).
} 
the Convention. ${ }^{1567}$ The Court also uses these methods to interpret treaties concluded before the VCLT's entry into force. ${ }^{1568}$ Like the Swiss Federal Tribunal, the Court has used the methods of the VCLT in connection with treaties concluded between Switzerland and subjects of international law other than States, eg to the 1972 Free Trade Agreement between Switzerland and the EEC. ${ }^{1569}$ The Court likewise relies on these methods to interpret the OECD Model Tax Convention and its commentaries. ${ }^{1570}$

Compared to the abovementioned examples, the Court is sometimes more cautious when assessing the customary character of the methods of the VCLT. It seems to consider that the VCLT has crystallized CIL, ie, that it has contributed to the emergence of customary law, and not simply codified it. The SFAC has for instance stated that the methods of the VCLT codify CIL 'in their essential content'. ${ }^{1571} \mathrm{~A}$ particularly informative example is a case on the Treaty of Turin of 1816 in which the Court analyzed the methods of treaty interpretation. The Court cited doctrinal analyses published in the 18th, 19th, and early 2 oth century, ${ }^{1572}$ and an advisory opinion of the PCIJ on the issue. ${ }^{1573}$ It concluded that the methods of the VCLT already existed in an 'analogous, although possibly less elaborate' form in the 18th century, and when the Treaty of Turin was concluded. ${ }^{1574}$ Another symptom of the Court's cautious appraisal of the customary character of the Convention's methods is the frequent mention of the date at which the VCLT entered into force in Switzerland, ${ }^{1575}$ as if it were necessary to demonstrate that the methods of the Convention are indeed

1567 SFAC, judgment A-7789/2009 of 21 January 2010, at 3.5; SFAC, judgment A-2677/2007 of 16 January 2009, at 3.2.1, 4.1.1; SFAC, judgment A-6633/2010 of 6 June 2011, at 4.2.3; SFAC, judgment C-6631/2010 of 15 June 2012, at 5.1.

1568 SFAC, judgment A-7789/2009 of 21 January 2010, at 3.6.1; SFAC, judgment A-2708/2013 of 28 August 2013, at 3.3.1. Regarding the 1951 Refugee Convention, for instance, the Court has stated that the methods of the VCLT apply 'not directly, but qua expression of the general rules of international law'. See SFAC, judgment C-7063/2008 of 15 May 2009, at 3.3.1.1.

1569 SFAC, judgment A-2708/2013 of 28 August 2013, at 3.3.1.

1570 SFAC, judgment A-7789/2009 of 21 January 2010, at 3.6.2.

1571 SFAC, judgment A-340/2015 of 28 November 2016, at 4.1.3.2; SFAC, judgment A-2677/ 2007 of 16 January 2009, at 3.2.2 ('in ihrem wesentlichen Gehalt'). See however ibid, at 4.1.1.

1572 SFAC, judgment A-340/2015 of 28 November 2016, at 4.1.3.4.

1573 Ibid, at 4.1.3.5.

1574 Ibid, at 4.1.3.6.

1575 SFAC, judgment A-4110/2010 of 9 May 2011, at 4.1; SFAC, judgment A-2677/2007 of 16 January 2009, at 3.2.1; SFAC, judgment A-6920/2010 of 21 September 2011, at 3.4.1; SFAC, judgment A-6262/2010 of 8 April 2011, at 3.2. 
applicable to treaties ratified by Switzerland. This conclusion would already follow from their customary source.

An interesting insight is that the Court has referred to the notion of 'pragmatic methodological pluralism' (see supra, Chapter 3, 4.2.6) in the context of treaty interpretation. ${ }^{1576}$ This confirms a trend that is often implicit in the practice, namely that this approach is used by Swiss courts with regard to both domestic and international law. 1577

The SFAC often cites the methods of the VCLT to stress that treaties must be interpreted independently from domestic law. The Court has pointed this out in numerous cases (the content of which is highly repetitive) pertaining to the UBS Agreement and its Protocol. ${ }^{1578}$ As previously noted, this does not mean that the methods of the VCLT are structurally different from those of domestic law, but only that interpreters cannot disregard the characteristics of international lawmaking. The VCLT is also mentioned when the conditions set out in art. 3(2) OECD Model Tax Convention (which specifies when courts may resort to domestic legal concepts to interpret tax treaties) do not apply. ${ }^{1579}$ Relatedly, the Court regularly mentions the VCLT, sometimes with an emphasis on art. 26 VCLT, to stress the importance of interpreting treaties in good faith ('[frei] von Spitzfindigkeiten und Winkelzügen'). ${ }^{1580}$

The Court has mentioned the methods of the VCLT when referring to the principle of auto-interpretation. It has done so several times in connection with the interpretation of the Swiss-US DTA, ${ }^{1581}$ but also with regard to the Free Trade Agreement of 1972 between Switzerland and the EEc. ${ }^{1582}$ As regards

1576 SFAC, judgment C-7063/2008 of 15 May 2009, at 3.3.1.1.

1577 In a case concerning the UBs Agreement, for instance, the Court has noted that interpretation pursuant to art. 31 VCLT is a 'unitary operation', and that the various methods are on equal footing. This is consistent with pragmatic methodological pluralism. See SFAC, judgment A-6927/2010 of 13 October 2011, at 8.1 f. See also SFAC, judgment A-6938/2010 of 14 July 2011, at 5.1.4.4; SFAC, judgment A-2866/2011 of 12 December 2011, at 4.1.

1578 SFAC, judgment A-6179/2010 of 3 March 2011, at 2.3.1. See also SFAC, judgment A-6677/2010 of 6 June 2011, at 3.2; SFAC, judgment A-7397/2010 of 19 August 2011, at 4.2; SFAC, judgment A-6941/2010 of 11 August 2011, at 4.2; SFAC, judgment A-6927/ 2010 of 13 October 2011, at 9.2.

1579 SFAC, judgment A-6638/2010 of 9 May 2011, at 4.1; SFAC, judgment A-3425/2010 of 11 April 2011, at 4.1; SFAC, judgment A-6944/2010 of 7 September 2011, at 8.3.3.

158 o SFAC, judgment A-7789/2009 of 21 January 2010, at 3.5.3. The Court has also stated that this duty merely applies to the relationship between the treaty parties. See SFAC, judgment A-4013/2010 of 15 July 2010, at 8.1.

1581 SFAC, judgment A-7789/2009 of 21 January 2010, at 6.5.2. See also SFAC, judgment A-6939/2010 of 27 June 2011, at 4.3; SFAC, judgment A-6053/2010 of 10 January 2011, at 5.3; SFAC, judgment A-6792/2010 of 4 May 2011, at 6.3.

1582 SFAC, judgment A-2708/2013 of 28 August 2013, at 3.3.1. 
the Swiss-EU Agreement on the Free Movement of Persons, however, the Court - like the Swiss Federal Tribunal (supra, 3.3.1.2) - considers that it must in principle be interpreted in 'parallel' to the CJEU's case law. ${ }^{1583}$

Interestingly, the Court has noted that courts are 'the primary - and probably sole - addressees' of the VCLT's methods, ${ }^{1584}$ as they are the instances to which States and Ios have delegated the competence of settling their disputes. ${ }^{1585}$ Strictly speaking, however, the duty bearers of art. 31 and $3^{2}$ VCLT are States. Moreover, other State organs, and especially the executive, need to resort to the VCLT as well.

In rare instances, the Court has mentioned the practice of the State authorities (and especially of the courts) of Switzerland's treaty partners when interpreting treaties. ${ }^{1586}$ In an overwhelming majority of cases, however, it primarily relies on legal scholarship and on Swiss case law (mostly its own and that of the Swiss Federal Tribunal) to underpin its statements regarding art. $31 \mathrm{f} \mathrm{VCLT.}{ }^{1587}$ Through this self-referential and even circular tendency, the Court neglects the primarily interstate nature of international lawmaking.

While many rulings refer to art. $31 \mathrm{f} \mathrm{VCLT} \mathrm{in} \mathrm{an} \mathrm{exhaustive} \mathrm{fashion,} \mathrm{the} \mathrm{level}$ of detail of the Court's case law on treaty interpretation is uneven. While this may be due to the fact that not every dispute raises equally salient interpretative issues, it can jeopardize the quality of judicial reasoning. The Court often cites the VCLT's provisions on interpretation pro forma, without subsequently applying its different methods. ${ }^{1588}$ In some cases, however, it has been remarkably thorough when applying these methods, eg in a case pertaining to the DTA between Switzerland and Singapore, ${ }^{1589}$ and in a case pertaining to the UBS Agreement, ${ }^{1590}$ but also in human rights cases, eg in a ruling of 2010 on the Refugee Convention. ${ }^{1591}$

1583 SFAC, judgments C-4032/2014 and C-7520/2014 of 3 November 2016, at 2.3. On the problems connected to this approach, see Besson and Ammann (n 97); Ammann, 'La non-discrimination, principe charnière d'interprétation: l'exemple de l'art. 2 ALCP' (n 1369).

1584 SFAC, judgment A-7789/2009 of 21 January 2010 , at $3 \cdot 5$.

1585 SFAC, judgment A-1735/2011 of 21 December 2011, at 2.2.

1586 SFAC, judgment A-7789/2009 of 21 January 2010, at 6.5.2; SFAC, judgment A-6159/2010 of 10 February 2011, at 3.4.2 (which pertains to the interpretation of Us constitutional law by Us courts).

1587 SFAC, judgment A-7789/2009 of 21 January 2010, at 3.5; SFAC, judgment A-2866/2011 of 12 December 2011, at 7.1.3.

1588 SFAC, judgment A-6179/2010 of 3 March 2011, at 2.3.1 ff; SFAC, judgment A-4110/2010 of 9 May 2011, at 4.1; SFAC, judgment C-7063/2008 of 15 May 2009, at 3.3.1.1 ff.

1589 SFAC, judgment A-4683/2010 of 12 May 2011, at 6.3.

1590 SFAC, judgment A-6962/2010 of 18 July 2011 , at $4.4 .4 \mathrm{ff}$.

1591 SFAC, judgment E-4207/2006 of 11 September 2008. 
The Court adopts distinctive approaches for specific treaties. This feature of the case law is not necessarily problematic, as long as the basic interpretative methods are used, and as long as these hermeneutic peculiarities are identified based on a predictable, clear, and consistent assessment. In connection with the UBs Agreement, for instance, the Court has noted that the vCLT applies unless the treaty contains special interpretative provisions. ${ }^{1592}$ Another example of lex specialis are provisions drafted based on art. 3(2) of the OECD Model Tax Convention. ${ }^{1593}$ The Court has also noted that whether the concept of effet utile applies to tax treaties is disputed. ${ }^{1594}$ The Court hereby neglects that the relevance of effet utile to treaty interpretation in general is controversial. The ILC explicitly refrained from including effet utile in the VCLT. ${ }^{1595}$

A related issue that is problematic from the perspective of legality and quality is that the Court's statements pertaining to the methods of art. $31 \mathrm{f} \mathrm{VCLT}$ are detailed, but highly repetitive. This suggests that the Court does not actually examine every method and its implications in every case but, instead, uncritically relies on blocks of text used in earlier cases. This tendency is corroborated by the fact that most of these detailed rulings date from 2011 and 2012 and pertain to the UBS Agreement and to DTAs concluded by Switzerland.

The SFAC's case law on treaty interpretation is prolific enough to examine how the Court approaches the four methods of treaty interpretation, regardless of whether the Court explicitly refers to the VCLT or not.

The Court considers that the text is the starting point of treaty interpretation, ${ }^{1596}$ and that it must be interpreted 'out of itself', based on its ordinary meaning. ${ }^{1597}$ The SFAC has occasionally relied on dictionary definitions in the context of textual interpretation. ${ }^{1598}$ It has noted that a term's ordinary meaning does not necessarily coincide with the ordinary use of language, and that it can be based on specialized terminology. ${ }^{1599}$ The use of a term in the legal

1592 SFAC, judgment A-6927/2010 of 13 October 2011, at 8.1 f. On lex specialis, see SFAC, judgment A-7789/2009 of 21 January 2010, at 3.6.1 and 5.3; SFAC, judgment A-2866/ 2011 of 12 December 2011, at 4.5, 7.1.1.

1593 SFAC, judgment A-2866/2011 of 12 December 2011, at 4.5 and 7.1.1. However, according to the Court, such provisions must themselves be interpreted based on art. $31 \mathrm{f} \mathrm{VCLT.} \mathrm{See}$ ibid, at 4.5; SFAC, judgment A-1951/2017 of 22 August 2018, at 3.2.4.

1594 SFAC, judgment A-7789/2009 of 21 January 2010, at 3.5.2.

1595 ILC, 'Draft Articles on the Law of Treaties With Commentaries' (n 783 ) 219.

1596 SFAC, judgment E-4207/2006 of 11 September 2008, at 6.2.

1597 SFAC, judgment A-8261/2010 of 15 August 2011, at 3.2; SFAC, judgment A-6962/2010 of 18 July 2011 , at $4 \cdot 4 \cdot 5 \cdot 1$.

1598 SFAC, judgment A-6159/2010 of 10 February 2011, at 3.4.1.

1599 SFAC, judgment A-6053/2010 of 10 January 2011, at 6. See also SFAC, judgment A-8261/ 2010 of 15 August 2011, at 3.2. 
orders of the treaty parties provides evidence of this ordinary meaning. ${ }^{1600}$ While the text often limits the reach of other methods, such as teleology, ${ }^{1601}$ the opposite is true as well, eg when the Court notes that textual interpretation should not be 'excessively formalistic' by leading to the neglect of other methods. ${ }^{1602}$ Like the Swiss Federal Tribunal, the SFAC uses the infelicitous (supra, 3.3.1.2) expression of 'clear meaning.' ${ }^{1603}$ In a large number of rulings, the Court has referred to its own case law based on which the VCLT commands a primarily textual interpretation of treaties. ${ }^{1604}$ This shows that the Court tends to reason in a self-referential and even circular way, instead of consulting international legal practice.

The Court interprets the notion of context of art. 31(2) VCLT narrowly. ${ }^{1605}$ It has held that the context excludes circumstances relevant to the conclusion of the treaty (art. $32 \mathrm{VCLT}$ ), as well as non-textual elements. ${ }^{1606}$ This last point is unduly restrictive. According to the Court, the context encompasses the text, preamble, and appendices to the treaty, as well as any agreement that occurred between the parties when the treaty was concluded. ${ }^{1607}$ The Court rightly considers that there is no hierarchy between art. 31(2) and art. 31(3) vCLt. ${ }^{1608}$ Few cases deal with subsequent agreements (art. 31(3)(a) VCLT). However, in a very detailed ruling, the Court has mentioned them with regard to DTAs. ${ }^{1609}$ Subsequent practice (art. 31(3)(b) VCLT) has been cited occasionally. ${ }^{1610}$ Exceptionally, the Court has even gone beyond art. 31(3)(b) VCLT to refer to the practice of States that were not parties to the treaty. ${ }^{1611}$ Regarding systemic integration (art. 31(3)(c) VCLT), the Court has noted that it includes every international legal act applicable between the parties. ${ }^{1612}$ The Court's approach in

1600 SFAC, judgment A-6053/2010 of 10 January 2011, at 6 .

1601 SFAC, judgment A-7789/2009 of 21 January 2010, at 3.5.2.

1602 SFAC, judgment A-6962/2010 of 18 July 2011 , at 4.4.7.

1603 SFAC, judgment A-7789/2009 of 21 January 2010, at 3.7.2.

1604 SFAC, judgment A-6903/2010 of 23 March 2011, at 4.2.1.

1605 SFAC, judgment A-2866/2011 of 12 December 2011, at 4.3.

1606 SFAC, judgment A-6053/2010 of 10 January 2011, at 5.1.2.

1607 Eg a protocol or an exchange of letters. See SFAC, judgment A-701 $7 / 2010$ of 16 June 2011, at 8.1.4.

1608 SFAC, judgment A-2866/2011 of 12 December 2011, at 4.3; SFAC, judgment A-6053/ 2010 of January 10, 2011, at 5.1.2. Art. 31(3) VCLT, according to the Court, pertains to the so-called 'external context'. See SFAC, judgment A-7789/2009 of 21 January 2010, at $3 \cdot 5 \cdot 4$.

1609 SFAC, judgment A-7789/2009 of 21 January 2010, at 3·7.10.

1610 SFAC, judgment E-4207/2006 of 11 September 2008, at 6.1.

1611 SFAC, judgment A-813/2010 of 7 September 2011, at 7.4.2.4.

1612 SFAC, judgment A-2866/2011 of 12 December 2011, at 4.3; SFAC, judgment A-6962/ 2010 of 18 July 2011 , at 4.4.8. For examples of (explicit and implicit) uses of the principle 
the aforementioned cases contradicts its narrow interpretation of context in connection with art. 31(2) VCLT.

The Court's attitude towards teleology displays some contradictions as well. The Court has stated that the treaty's object and purpose concerns the goals the parties intended to (and can) ${ }^{1613}$ achieve through the treaty. ${ }^{1614}$ Surprisingly, the SFAC considers that whether teleological considerations can be relied on in the context of purposive interpretation is disputed. ${ }^{1615}$ The Court has held that the UBS Agreement aims at resolving a 'sovereignty conflict' between Switzerland and the United States, ${ }^{1616}$ but also that the political circumstances of its adoption are irrelevant to determine its object and purpose. ${ }^{1617}$ It views the treaty text (or its ordinary meaning) $)^{1618}$ as a constraint on purposive interpretation, ${ }^{1619}$ but it has highlighted a treaty's object and purpose to justify dynamic interpretations. ${ }^{1620}$ The Court has noted that the title and preamble of the treaty can be helpful to identify its object and purpose, ${ }^{1621}$ but also, on the other hand, that the VCLT does not clarify how the object and purpose ought to be determined. ${ }^{1622}$ As mentioned, the Court occasionally mentions the concept of effet utile, ${ }^{1623}$ although the ILC intentionally excluded it from art. 31 VCLT.

Historical interpretation is often conducted inconsistently with art. 32 VCLT. The Court sometimes conflates historical interpretation with the circumstances surrounding the treaty's conclusion. ${ }^{1624}$ Like the Swiss Federal Tribunal, the SFAC has erroneously mentioned the practice of the Swiss authorities

of systemic integration of art. 31(3)(c) VCLT, see also SFAC, judgment A-813/2010 of 7 September 2011, at 7.4.2.4; SFAC, judgment A-6159/2010 of 10 February 2011, at 3.4.5.2; SFAC, judgment A-4013/2010 of 15 July 2010, at 5 and 6.

1613 SFAC, judgment A-6258/2010 of 14 February 2011 , at 11.1.2.

1614 The Court has stressed that DTAs do not pursue the same goal as agreements that aim at combating tax fraud. See SFAC, judgment A-6053/2010 of 10 January 2011, at 5.1.3; SFAC, judgment A-4911/2010 of 30 November 2010, at 4.1.3.

1615 SFAC, judgment A-1735/2011 of 21 December 2011, at 2.2.2.

1616 SFAC, judgment A-4013/2010 of 15 July 2010, at 8.1; SFAC, judgment A-6962/2010 of 18 July 2011 , at 4.4.6.2.

1617 SFAC, judgment A-4013/2010 of 15 July 2010, at 8.1.

1618 SFAC, judgment A-6258/2010 of 14 February 2011, at 11.1.4, 11.3.5.

1619 SFAC, judgment A-8261/2010 of 15 August 2011, at 3.4.

1620 SFAC, judgment E-4207/2006 of 11 September 2008, at 6.4.2 (Refugee Convention).

1621 SFAC, judgment A-7789/2009 of 21 January 2010, at 3.5.2; SFAC, judgment A-6053/2010 of 10 January 2011 , at 5.1.3.

1622 See SFAC, judgment A-7789/2009 of 21 January 2010, at 3.5.2.

1623 SFAC, judgment C-7063/2008 of 15 May 2009, at 3.3.1.1.

1624 SFAC, judgment A-6053/2010 of 10 January 2011, at 5.1.2. See however SFAC, judgment A-4683/2010 of 12 May 2011, at 5.4.1. 
pertaining to the ratification of a treaty in connection with art. $3^{2}$ VCLT, ${ }^{1625}$ although it has stressed the irrelevance of such domestic preparatory work in other cases. ${ }^{1626}$ The Court does not strictly examine whether the conditions for resorting to the subsidiary means of art. 32 VCLT are indeed fulfilled, although it acknowledges their existence. ${ }^{1627}$ It is worth noting that the Court takes the OECD Model Tax Convention and its commentaries into account from the perspective of art. 32 VCLT to interpret DTAs drafted based on the OECD Model Tax Convention. ${ }^{1628}$ Moreover, in the context of the Refugee Convention, it consults the UNHCR Guidelines, again in the framework of art. 32 VCLT. ${ }^{1629}$

The Court's references to the VCLT cut both ways: they either highlight the advantages or the drawbacks of a given method. This confirms that all methods must be used jointly (supra, Chapter 6, 2.5). To illustrate, the SFAC sometimes cites the methods of the VCLT to emphasize purposive interpretation, ${ }^{1630}$ but

1625 SFAC, judgment A-3003/2017 of 1 May 2019, at 4.1.2 (mentioning the dispatch of the Swiss Federal Council on the approval of the Swiss-French DTA); SFAC, judgment A-840o/2015 of 21 March 2016, at 6.3.1.5 (where the Court accepted the possibility to rely on the protocol of the debates and final decision of the federal parliament to ratify the Swiss-Dutch DTA under the heading of art. 32 VCLT); SFAC, judgments A-44O7/ 2014, A-4414/2014, and A-4415/2014 of 8 December 2014, at 3.1.1 (mentioning the dispatch of the Swiss Federal Council on the approval of the Swiss-Dutch DTA); see also SFAC, judgment A-8400/2015 of 21 March 2016, at 6.3.1.5 (on the parliamentary debates on the Swiss-Dutch DTA); SFAC, judgment A-1735/2011 of 21 December 2011, at 5.4 (mentioning the dispatch of the Swiss Federal Council on the approval of the Swiss-EU Bilateral Agreements of 2004); SFAC, judgment A-4683/2010 of 12 May 2011, at 6.3.4, and SFAC, judgment A-4677/2010 of 12 May 2011, at 6.3.4 (mentioning the dispatch of the Federal Council on the approval of the DTA between Switzerland and Singapore). See also (mentioning the dispatch of the Federal Council on the approval of the Swiss-Us UBS Agreement): SFAC, judgment A-6641/2010 of 11 March 2011, at 5.2.2; SFAC, judgment A-6159/2010 of 10 February 2011, at 3.3.1; SFAC, judgment A-8261/2010 of 15 August 2011, at 4.4; SFAC, judgment A-3830/2010 of 29 April 2011, at 3.4.5; SFAC, judgment A-6792/2010 of 4 May 2011, at 8.3.3.

1626 SFAC, judgment C-6631/2010 of 15 June 2012 , at $5 \cdot 3$.

1627 SFAC, judgment A-6962/2010 of 18 July 2011 , at 4.4.4.

1628 SFAC, judgment A-6537/2010 of 7 March 2012, at 3.2.4; SFAC, judgment A-7789/2009 of 21 January 2010, at 3.6.2; SFAC, judgment A-1246/2011 of 23 July 2012, at 3.3.4. See also SFAC, judgment A-813/2010 of 7 September 2011, at 7.4.2.4 (mentioning the OECD commentary and a 'Technical Explanation' pertaining to the us Model Income Tax Convention of 1996).

1629 SFAC, judgment E-4207/2006 of 11 September 2008, at 6.1.

1630 SFAC, judgment A-6179/2010 of 3 March 2011, at 2.3.2. See also SFAC, judgment A-6677/ 2010 of 6 June 2011, at 3.3; SFAC, judgment A-7397/2010 of 19 August 2011, at 4.3; SFAC, judgment A-6941/2010 of 11 August 2011, at 4.2; SFAC, judgment A-6680/2010 of 27 September 2011, at 4.2; SFAC, judgment A-6927/2010 of 13 October 2011, at 9.2, 10.2; SFAC, judgment A-2866/2011 of 12 December 2011, at 7.1.3. 
also the limits that the text imposes on teleology. ${ }^{1631}$ In some cases, it has emphasized systematic interpretation ${ }^{1632}$ and, in others, its limited reach. ${ }^{1633}$

\subsubsection{The Swiss Federal Criminal Court}

Strikingly, since the beginning of its activity in 2004, the Swiss Federal Criminal Court (SFCC) has referred to the VCLT's interpretative methods only once, and very briefly. ${ }^{1634}$ However, it has mentioned other provisions of the Convention, ${ }^{1635}$ and it does occasionally apply treaty law, ${ }^{1636}$ including treaties that are barely applied by other Swiss courts. ${ }^{1637}$ Only a few cases on international law are more detailed, eg the Nezzar case pertaining to the law of immunities. ${ }^{1638}$ This case is primarily of interest from the perspective of CIL (infra, Chapter 8, 2.2.2.2).

The Court's case law on treaty interpretation is too scarce to enable an analysis of the SFCC's use of the different interpretative methods. Moreover, the Court does not dwell on the methods it uses to interpret the law (be it

1631 SFAC, judgment A-7789/2009 of 21 January 2010, at 3.5.2.

1632 SFAC, judgment A-8358/2010 of 25 October 2011, at 8.4. Interestingly, in SFAC, judgment A-7789/2009 of 21 January 2010 , at $3 \cdot 5 \cdot 2$, the Court notes that teleological interpretation is not explicitly mentioned in art. 31 VCLT.

$1633 \mathrm{Eg}$ when stressing that a treaty must be interpreted independently from other treaties. See SFAC, judgment A-6927/2010 of 13 October 2011, at 8.2, 10.2 .

1634 SFCC, judgment RR.2017.338 of 17 July 2018 , at 3.4.1 (status as of June 2019).

1635 As of June 2019, the Court's database (<bstger.weblaw.ch/index.php?method= gesreg\&f=o $>$ ) referenced 1 ruling mentioning art. 18 VCLT, 16 rulings mentioning art. 26 VCLT, 2 rulings mentioning art. 27 VCLT, and 2 rulings mentioning art. 30 VCLT. Many of these rulings are repetitive (ie, they reiterate what has already been said in a previous decision).

1636 According to the Court's official website, the Court has applied 20 different international agreements since 2004 (the two versions of the Lugano Convention are counted as one agreement, as well as the Swiss-us Agreement on Mutual Legal Assistance in Criminal Matters and its Appendix). See <bstger.weblaw.ch/index.php?method=gesreg\& $\mathrm{f}=0>$. The list does not include all treaties mentioned in the Court's case law, however; see for instance judgment RR.2013.229 of 16 October 2013, which mentions the UN Convention Against Corruption. Moreover, the database appears to contain errors: judgment Bв.2015.17 of 6 October 2015, which deals with the Federal Act on DNA Profiles (sR 363), has been miscategorized as referring to the European Agreement Concerning the International Carriage of Dangerous Goods by Inland Waterways (ADN Treaty, SR 0.747.208).

1637 Examples include the Geneva Conventions I, II, and III, or the European Convention on the Prevention of Terrorism. Other conventions that frequently appear in the SFCC's case law are also applied by other courts, eg the 1990 Convention of the Council of Europe on Money Laundering, which regularly appears in the case law of the Swiss Federal Tribunal. 1638 SFCC, judgment вв.2011.140 of 25 July 2012. 
domestic or international). Only a few observations can be made about the Court's practice.

First, contrary to that of the Swiss Federal Tribunal and of the SFAC, the SFCC's jurisdiction is narrow. Therefore, its case law is specialized. This may explain why the judges of the SFCC do not analyze the methods of treaty interpretation. Second, when interpreting treaties, the Court frequently cites its own case law, ${ }^{1639}$ which is in line with the self-referential practice of other federal courts. The Court also mentions the case law of other Swiss courts, especially rulings of the Swiss Federal Tribunal, ${ }^{1640}$ and the practice of other Swiss authorities, eg the Swiss Federal Council and, more generally, the Swiss federal administration. ${ }^{1641}$ It rarely refers to rulings of international courts. ${ }^{1642}$ In Nezzar, the SFCC cited the ICRC commentary and the website of a Belgian think tank in connection with art. 3 AP II to the Geneva Conventions. ${ }^{1643}$ The use of such materials is exceptional in the Swiss case law, and is probably due to the political sensitivity of the case. Third, the Court frequently relies on scholarly writings. ${ }^{1644}$ While using such materials undoubtedly serves judicial economy, it may prevent a thorough engagement with the issue at stake. In Nezzar, for instance, the Court relied on scholarly analyses of the relationship between some provisions of domestic criminal law and other treaties ratified by Switzerland. ${ }^{1645}$ It stated that the domestic provision created 'a conflict with the Geneva Conventions, of which Switzerland is the depositary'. It did so based on scholarly writings and on the fact that 'no scholar argue[d] otherwise,'1646 a

1639 SFCC, judgment RR.2013.229 of 16 October 2013, at 3.1 (regarding the European Convention on Extradition of 1957); SFCC, judgments RR.2011.144-148 of 26 January 2012, at 6.1 (regarding the European Convention on Mutual Assistance in Criminal Matters of 1959).

1640 SFCC, judgment RR.2013.229 of 16 October 2013, at 6.1 and 8.1 (regarding the ECHR), and at 8.4 (regarding the principle of good faith between States); SFCC, judgments RR.2011.144-148 of 26 January 2012, at 6.4.3 (regarding the European Convention on Mutual Assistance in Criminal Matters of 1959).

1641 SFCC, judgment вв.2011.140 of 25 July 2012, at 3.4 and 3.6 (regarding the implementation of the ICC Statute), and $5 \cdot 3$ (regarding the VCDR).

1642 SFCC, judgment RR.2013.229 of 16 October 2013, at 8.3, and SFCC, judgment RR.2009.163 of 22 July 2009, at 3.6 (citing the case law of the ECtHR on the ECHR); SFCC, judgment вв.2011.140 of 25 July 2012 , at 3.5 (regarding the case law of the ICJ, used in connection with the interpretation of art. 3 AP II).

1643 SFCC, judgment Bв.2011.140 of 25 July 2012 , at 3.5 .

1644 SFCC, judgment RR.2013.229 of 16 October 2013, at 3.1 (regarding the European Convention on Extradition of 1957).

1645 Ie, the Genocide Convention and the Geneva Conventions. See SFCC, judgment BB.2011.140 of 25 July 2012 , at 3.3.1.

1646 Ibid, at 3.3.2. 
statement which fails to convince. In this case, the Court also used scholarship to interpret the $\mathrm{VCDR}^{1647}$ and the ICC Statute. ${ }^{1648}$

\subsubsection{Cantonal Courts}

Cantonal courts have referred to the methods of the VCLT in some cases dealing with treaties. This subsection analyzes the case law of the Supreme Court of the canton of Geneva (3.3.3.1), the High Court and Administrative Court of the canton of Zurich (3.3.3.2), the Court of Appeals of the canton of Basel-Stadt (3.3.3.3), and the High Court and Administrative Court of the canton of Bern (3.3.3.4) (on the reasons for this focus, see supra, Chapter 3, 4.1.2). Relevant case law is scarce (though not as meagre as that of the SFCC, for instance, see supra, 3.3.2.2), which makes it difficult to assess how these courts use the methods of treaty interpretation. The following paragraphs hence merely address their overall approach.

\subsubsection{The Supreme Court of the Canton of Geneva}

Out of the four cantonal courts under scrutiny, it is the Supreme Court of the canton of Geneva that most frequently refers to treaty law. It mostly cites the Vienna Convention in administrative law cases. The Court's Civil, Criminal, and Constitutional Chambers never appear to cite the VCLT's methods, contrary to its Administrative Chamber and, occasionally, its Social Insurance Chamber. The Court has used the VCLT's methods to interpret DTAs, the Swiss-EU Agreement on the Free Movement of Persons, and Social Security Agreements. I analyze these three clusters of cases in turn.

The Court's approach to the methods of treaty interpretation has been particularly detailed - albeit modelled on the Swiss Federal Tribunal's case law with regard to DTAs. ${ }^{1649}$ The Court has referred to the case law of the Swiss Federal Tribunal to justify the applicability of the VCLT's methods. ${ }^{1650}$ The Court rarely cites the methods of the VCLT in a predictable, clear, and consistent way. ${ }^{1651}$ It considers the text to be the starting point of the interpretation

\footnotetext{
1647 Ibid, at $5 \cdot 3$.

1648 Ibid, at $5 \cdot 3 \cdot 5$.

1649 CJ-GE, Chambre administrative, judgment ATA/434/2016 of 24 May 2016, at 5; CJ-GE, Chambre administrative, judgment ATA/270/2011 of 3 May 2011, at 6; CJ-GE, Chambre administrative, judgment ATA/238/2011 of 12 April 2011, at 10; CJ-GE, Chambre administrative, judgment ATA/328/2004 of 27 April 2004, at 5 c).

1650 CJ-GE, Chambre administrative, judgment ATA/434/2016 of 24 May 2016, at 5 a); CJ-GE, Chambre administrative, judgment ATA/270/2011 of 3 May 2011, at 6; CJ-GE, Chambre administrative, judgment ATA/238/2011 of 12 April 2011, at 10.

1651 CJ-GE, Chambre administrative, judgment ATA/270/2011 of 3 May 2011, at 6. See however CJ-GE, Chambre administrative, judgment ATA/238/2011 of 12 April 2011, at $10 \mathrm{ff}$.
} 
of DTAs, and that the main purpose of these agreements is to avoid double taxation, as opposed to avoiding taxation altogether. ${ }^{1652}$ The Court has also cited a Swiss scholarly treatise on the issue. ${ }^{1653}$ Interestingly, and although this could have been avoided easily, the Court even cited this treatise in disputes where the author of the book was also the lawyer of one of the parties. ${ }^{1654}$ The Court has sometimes relied on the Swiss Federal Tribunal's case law to determine the object and purpose of DTAs. ${ }^{1655}$ Contrary to what art. 32 VCLT provides, the Court has referred to the Swiss travaux pertaining to some DTAS. ${ }^{1656}$

The Court regularly notes that the methods of the Vienna Convention apply to the Swiss-EU Agreement on the Free Movement of Persons, and that Swiss judges must interpret the Agreement independently from the CJEU's case law, at least when this case law was issued after the Agreement's signature by the parties (art. 16(2) of the Agreement). ${ }^{1657}$ Despite this reference to the VCLT, the Court has not applied the Convention's methods to the Swiss-EU Agreement on the Free Movement of Persons in a predictable, clear, and consistent way. ${ }^{1658}$ To interpret it, the Court has cited the case law of the Swiss Federal Tribunal and its own case law, as well as scholarship. ${ }^{1659}$

1652 CJ-GE, Chambre administrative, judgment ATA/434/2016 of 24 May 2016, at 5 c).

1653 Ibid, at 5 b). See also CJ-GE, Chambre administrative, judgment ATA/328/2004 of 27 April 2004, at $5 \mathrm{c}$ ).

1654 CJ-GE, Chambre administrative, judgment ATA/434/2016 of 24 May 2016, at 5 b).

1655 CJ-GE, Chambre administrative, judgment ATA/289/200o of 9 May 2000, at 4 a).

1656 CJ-GE, Chambre administrative, judgment ATA/434/2016 of 24 May 2016, at 5 c) (regarding the Swiss-Israeli DTA of 2003); CJ-GE, Chambre administrative, judgment ATA/238/ 2011 of 12 April 2011, at 15 (regarding the DTA between Switzerland and the United Kingdom and Northern Ireland of 1993).

1657 CJ-GE, Chambre administrative, judgment ATA/551/2012 of 21 August 2012, at 8 b); CJ-GE, Chambre administrative, judgment ATA/43/2011 of 25 January 2011, at 9; CJ-GE, Chambre administrative, judgment ATA/633/2009 of 1 December 2009, at 11; CJ-GE, Chambre administrative, judgment ATA/152/2009 of 24 March 2009, at 23; CJ-GE, Chambre administrative, judgment ATA/23/2014 of 14 January 2014, at 9 b); CJ-GE, Chambre des assurances sociales, judgment ATAs/9o9/2013 of 19 Septembre 2013, at 6 d); CJ-GE, Chambre des assurances sociales, judgment ATAS/503/2014 of 10 April 2014, at $6 \mathrm{c}$ ).

1658 CJ-GE, Chambre administrative, judgment ATA/23/2014 of 14 January 2014, at 9 b); CJ-GE, Chambre administrative, judgment ATA/551/2012 of 21 August 2012, at 8 b).

1659 CJ-GE, Chambre administrative, judgment ATA/23/2014 of 14 January 2014, at 9 b); CJ-GE, Chambre administrative, judgment ATA/551/2012 of 21 August 2012, at 8 b); CJ-GE, Chambre administrative, judgment ATA/43/2011 of 25 January 2011, at 9 ; CJ-GE, Chambre administrative, judgment ATA/633/2009 of 1 December 2009, at 11; CJ-GE, Chambre administrative, judgment ATA/152/2009 of 24 March 2009, at 23. 
The Court has also applied the vCLT's methods to the Swiss-us Social Security Agreement. In line with the Swiss Federal Tribunal's practice (supra, 3.3.1.1), it has noted that the VCLT introduced some changes in the methods used by the highest court to interpret such treaties, especially because it requires that treaty terms be in principle interpreted independently from domestic law. ${ }^{1660}$ The Court has also stated that the interpretation of an exchange of letters between the Swiss government and the wHO is governed by the VCLT. ${ }^{1661}$

Overall, hardly any ruling of the Court uses the methods of the VCLT in a predictable, clear, and consistent way. The methods of the Convention are often referenced at the beginning of the interpretative process, but they are seldom applied in a rigorous fashion.

\subsubsection{The High Court and the Administrative Court of the Canton of Zurich} The High Court and Administrative Court of the canton of Zurich do not frequently refer to the methods of the vCLT. Some decisions of the High Court follow the Swiss Federal Tribunal's case law on treaty interpretation and, thereby, the methods of the VCLT, ${ }^{1662}$ though often implicitly. ${ }^{1663}$ In several judgments dating from 2018 and pertaining to the Swiss-EU Agreement on the Free Movement of Persons, the High Court held that the treaty was not to be interpreted based on domestic law, but 'out of itself, in good faith, and in light of its object and purpose', yet the Court did not mention the VCLT. ${ }^{1664}$ Only a handful of cases deal with the methods of treaty interpretation, and the courts' approach is not always in line with the broader Swiss and international practice and/or with the vCLT.

A High Court decision of 1997 highlights, in addition to restrictive interpretation, that treaty interpretation aims at identifying the intentions of the parties. ${ }^{1665}$ These two positions are somewhat dated, and they are not commonly

1660 CJ-GE, Chambre des assurances sociales, judgment ATAS/507/2017 of 15 June 2017, at 9; CJ-GE, Chambre des assurances sociales, judgment ATAS/495/2016 of 23 June 2016, at $10 \mathrm{c})$.

1661 CJ-GE, Chambre des assurances sociales, judgment ATAs/813/2015 of 28 October 2015 , at 5 .

1662 'Obergericht, II. Zivilkammer, Beschluss vom 8. April 2002' (2002) 101 Blätter für Zürcherische Rechtsprechung 276, para 3.1.

1663 See however VwGer-ZH, judgment SB.2012.00o88 of 18 December 2013, at 20.

1664 OGer-ZH, judgment SB 170315 of 16 January 2O18, at 2 b); OG er-ZH, judgment SB 180164 of 5 October 2018 , at 2 c); OGer-ZH, judgment SB180165 of 5 October 2018, at $2 \mathrm{c}$ ); OGer-ZH, judgment SB 180235 of 5 October 2O18, at 7.2. An indirect reference to the VCLT can be found in a later case in which the Court quotes the Swiss Federal Tribunal: OG erZH, judgment SB 180098 of 26 February 2019, at 6.2.

1665 'Obergericht, I. Zivilkammer, Beschluss vom 11. April 1997' (1997) 96 Blätter für Zürcherische Rechtsprechung 261, para 2. 
adopted in the Swiss case law. Some decisions stress the importance of 'autonomous interpretation.' 1666

The Administrative Court has inquired into the intentions of the treaty parties as well. ${ }^{1667}$ In a ruling of 2003 pertaining to the Swiss-EU Agreement on the Free Movement of Persons, it stressed the wording, object and purpose, and context of the agreement. ${ }^{1668}$ Contrary to what art. $31 \mathrm{f} \mathrm{VCLT}$ allow, it also emphasized the 'Swiss perspective' on the agreement's object and purpose. ${ }^{1669}$ In another decision of 2003, the Administrative Court highlighted the object and purpose of the Swiss-EU Agreement, noting that Switzerland had 'not been able to carry through its position' on some aspects and had 'de facto been forced to adopt EU law' ${ }^{\prime 670}$ These statements could suggest that the Court is influenced by partisan motives. By contrast, in a ruling of 2013, the Court mentioned the case law of the Swiss Federal Tribunal to state that DTAs must be interpreted based on the VCLT's methods. ${ }^{1671}$ It is worth noting that it sometimes merely recites the provisions of a treaty without interpreting them. ${ }^{1672}$

\subsubsection{The Court of Appeals of the Canton of Basel-Stadt}

As a reminder, the Court of Appeals of the canton of Basel-Stadt is the highest judicial body of the canton in civil, criminal, administrative, and constitutional matters (supra, Chapter 3, 4.1.2.3). Deciding in its administrative court capacity, the Court of Appeals has relied on art. $31 \mathrm{f} \mathrm{VCLT}$ and on the case law of the Swiss Federal Tribunal to interpret an agreement between the BIS and the canton of Basel-Stadt. ${ }^{1673}$ In a judgment of 2018 pertaining to the UN Convention on Contracts for the International Sale of Goods, the Court stressed that interpreters had to take the international character of the Convention into account. It mentioned the four interpretative methods of international law, as well as the comparative law method. The Court further emphasized the importance of aiming for 'practicable' interpretative outcomes. ${ }^{1674}$ Overall, however,

1666 'Obergericht, II. Zivilkammer, Beschluss vom 30. September 2005' (2005) 106 Blätter für Zürcherische Rechtsprechung 33, para 1.

1667 Eg VwGer-ZH, judgment VB.2013.00274 of 4 September 2014, at 6.3.4.

1668 VwGer-ZH, judgment VB.2003.00175 of 22 October 2003, at 2-4.

1669 Ibid, at $4 \mathrm{~h})$.

1670 VwGer-ZH, judgment vB.2002.00405 of 19 March 2003, at 3 d).

1671 VwGer-ZH, judgment sB.2012.00o88 of 18 December 2013, at 20. See also VwGer-ZH, judgment SB.2016.00118 of 31 May 2017, at 2.2.1.

1672 Eg VwGer-ZH, judgment VB.2013.00274 of 4 September 2014.

1673 'Urteil des Verwaltungsgerichts vom 17.8.2001 in Sachen Ehegatten X.-Y'. (2003) Basler Juristische Mitteilungen 214, para $2 \mathrm{c}$ ).

1674 AG-BS, judgment ZB.2017.20 of 24 August 2018, at 3.2. 
very few cases deal with treaties in the first place, let alone with their interpretative methods.

\subsubsection{The High Court and the Administrative Court of the Canton of Bern} As a general matter, very little case law of the High Court and Administrative Court of the canton of Bern that is available online deals with the methods of treaty interpretation, although treaties are mentioned in some decisions. The High Court hardly ever refers to the vCLT's methods. The Administrative Court has noted that the Swiss-Eu bilateral agreements must be interpreted 'autonomously', pursuant to the methods of the vCLT. ${ }^{1675}$ However, only very few of its rulings refer to the VCLT and to its methods. In a detailed judgment pertaining to the Swiss-Thai DTA, and based on the practice of the Swiss Federal Tribunal and legal scholarship, the Administrative Court stated that DTAs must be interpreted pursuant to CIL and the vCLT. It especially referred to textual and systemic interpretation (with unusually copious references to other DTAS concluded by Switzerland), ${ }^{1676}$ insisting on the fact that its interpretation was consistent with the Swiss Federal Tribunal's case law. ${ }^{1677}$ In another, equally detailed judgment of 2018 pertaining to the Swiss-Thai DTA, the Court stated that unilateral declarations issued by one of the treaty partners were not part of the context of the treaty as per art. 31(2) VCLT, thereby rejecting the argumentation of the federal tax authorities. ${ }^{1678}$ Such rulings are exceptional occurrences in the case law.

\subsubsection{Military Tribunals}

Many decisions of the MCC $^{1679}$ concern alleged failures of members of the military to comply with their duty to serve. As regards the MCC's interpretative

1675 'Urteil des Verwaltungsgerichts (Sozialversicherungsrechtliche Abteilung) vom 28. Dezember 2012 in Sachen B. gegen Gemeinsame Einrichtung KVG (VGE 200.2012.892)' (2013) Bernische Verwaltungsrechtsprechung 487, para 3; 'Auszug aus dem Urteil des Verwaltungsgerichts (Sozialversicherungsrechtliche Abteilung) vom 14. Januar 1999 in Sachen P.K. gegen Arbeitslosenkasse AdU (AlV 53180)' (1999) Bernische Verwaltungsrechtsprechung 373 , para 5 a).

1676 VwGer-BE, judgment 100201412 of 20 April 2016, at $5.1 \mathrm{ff}$.

1677 Ibid, at 5.5.

1678 VwGer-BE, judgment 100201727 of 1 May 2018, at 5.2 (pertaining to VwGer-BE, judgment 100201412 of 20 April 2016). See also VwGer-BE, judgment 100201724 of 29 June 2018, at 4.3.1.

1679 As mentioned in Chapter 3, the present analysis includes the decisions of the Military Court of Cassation (MCC) accessible online since 2006, see <www.oa.admin.ch/de/ entscheidungen-militaerjustiz.html $>$. Scope precluded a systematic analysis of the Court's comprehensive database (available at <eu.alma.exlibrisgroup.com/view/delivery/ 41BIG_INST/12329504630001791\#main-carousel $>$ ). Decisions of the lower military 
methods in general, the Court has endorsed the Swiss Federal Tribunal's 'pragmatic methodological pluralism.' ${ }^{1680}$ Overall, the MCC mentions treaties very rarely. ${ }^{1681}$ One of the few cases in which treaty law was applied is a decision of 2011 pertaining to the 2007 Swiss-Italian Convention on the military service of dual nationals. ${ }^{1682}$ The Court only lists a number of provisions of the Convention. It does not provide insights into the methods of treaty interpretation. The same applies to another case of 2012 pertaining to the same treaty. ${ }^{1683}$ While some decisions of the MCC mention the ECHR, they primarily use the case law of the Swiss Federal Tribunal to interpret the Convention. ${ }^{1684}$ In a decision of 2013, the Court interpreted art. 5 ECHR based on scholarly writings. ${ }^{1685}$

A landmark case in which the Court applied international law is the Niyonteze judgment, decided in 2001. ${ }^{1686}$ The case mainly pertained to common art. 3 of the Geneva Conventions and their Additional Protocol II (AP II). The Court also interpreted the former art. 109 of the Swiss Military Criminal Code (SMCC), which sanctioned violations of IHL treaties. ${ }^{1687}$ Unfortunately, the case does not reveal the methods based on which these treaty provisions must be interpreted. To interpret common art. 3, the Court referred to the ICTY's case law ${ }^{1688}$ and to the ICRC commentary on AP II. ${ }^{1689}$ It also relied on the ICTR's practice to establish the existence of a non-international armed conflict pursuant to common art. $3 .{ }^{1690}$ To clarify the notions of intentional homicide or murder under IHL, the Court mentioned a dispatch of the Federal

courts were not surveyed systematically, although I occasionally mention rulings deemed relevant. Given the absence of a search engine that can identify relevant decisions of the military courts, the survey of the MCC's recent decisions was complemented by scholarship and case reports by NGOs or other private or public bodies.

1680 MCC, judgment of 14 December 2012, DMC Vol 13 No 34, at 2 b); MCC, judgment of 19 September 2013, DMC Vol 13 No 39, at 3.2.1.

1681 For a case presenting an international dimension, but in which no treaty between Switzerland and Turkey had been concluded, see MCC, judgment of 10 December 2009, DMC Vol 13 No 17, at 2 a). See however ibid, at 2 d) (reference to treaties with other States than Turkey).

1682 MCC, judgment of 21 September 2011, DMC Vol 13 No 28.

1683 MCC, judgment of 14 December 2012, DMC Vol 13 No 35, at 3.2.

1684 MCC, judgment of 24 April 2007, DMC Vol 13 No 3, at 3, and MCC, judgment of 24 April 2007, DMC Vol 13 No 4, at 3; MCC, judgment of 20 June 2013, DMC Vol 13 No 38, at 3.2.

1685 MCC, judgment of 8 February 2013, DMC Vol 13 No 36 , at 2 b) aa).

1686 MCC, judgment of 27 April 2001, DMC Vol 12 No 21 (the decision is available at <eu.alma. exlibrisgroup.com/view/delivery/41BIG_INST/12329504630001791>).

1687 See also art. $110 \mathrm{ff} \mathrm{SMCC} \mathrm{(as} \mathrm{of} 1$ January 2019).

1688 MCC, judgment of 27 April 2001, DMC Vol 12 No 21, at 3 c).

1689 Ibid, at 9 a).

1690 Ibid, at $3 \mathrm{~d})$. 
Council. ${ }^{1691}$ It noted that as the highest military court, it had to interpret art. 109 SMCC autonomously. ${ }^{1692}$ Whether it was alluding to its hierarchical position in the Swiss military judiciary or to its autonomy from international courts is unclear. ${ }^{1693}$

\subsection{Relationship with Interpretative Methods under Swiss Law}

How do the methods used by Swiss courts to interpret treaties relate to those they employ to interpret Swiss law? Given the richness and influential character of the Swiss Federal Tribunal's case law regarding domestic interpretative methods, the Court constitutes my focus in this subsection.

In the context of domestic statutory ${ }^{1694}$ and constitutional ${ }^{1695}$ interpretation, but also with regard to other domestic legal acts ${ }^{1696}$ (and even before their formal adoption), ${ }^{1697}$ the Swiss Federal Tribunal uses the same four interpretative methods as those governing the interpretation of international law (supra, Chapter 6, section 2). This is true even though the way in which these methods are used can vary, inter alia depending on the legal source at stake. ${ }^{1698}$ It is important to acknowledge that in domestic interpretation as well, the legality and quality of the Court's reasoning are sometimes problematic. ${ }^{699}$

The Swiss Federal Tribunal has explicitly acknowledged that the basic methods of treaty interpretation and the methods of domestic statutory interpretation ${ }^{1700}$ (and, more generally, the interpretative methods of 'general and abstract rules of domestic law' $)^{1701}$ are the same. Given the monism of the

1691 Ibid, at 9 a).

1692 Ibid, at $9 \mathrm{~d})$.

1693 The remarks of the MCC suggest that it is probably the former, as the Court then stated that there was no reason not to adopt the criteria used by the ICTR to determine whether common art. 3 and AP II had been violated. See ibid, at $9 \mathrm{~d}$ ).

1694 BGE 141 III 155, at 4.2; BGE 14 O IV 28, at 4.3.1; BGE 123 II 595, at 4 a).

1695 BGE 83 I 173, at 4 (interpretation of a cantonal constitution); BGE $118 \mathrm{Ib} \mathrm{187}$, at 4, and BGE 116 Ia 359, at 5 c) (interpretation of the Cst.).

$1696 \mathrm{Eg} \mathrm{BGE} 137$ I 31, at 2, and BGE 140 I 2, at 4 (interpretation of an intercantonal agreement); BGE 102 II 4O1, at 3, and BGE 137 III 337, at 3 (interpretation of a federal ordinance); BGE 140 III 349, at 2.3 (interpretation of the bylaws of large corporations).

1697 BGE 124 I 107, at 5 b) (interpretation of a cantonal popular initiative).

1698 In the context of constitutional interpretation, for instance, the Court is more cautious to use evolutive (teleological) interpretation. See BGE 115 Ia 127, at 3 a) (where the Court also distinguishes between so-called organic provisions and provisions protecting fundamental rights).

1699 For a critique, see Pichonnaz and Vogenauer (n 105). See also Chapter 3, 4.2.6 (supra).

1700 Eg BGE 136 I 290, at 2.3.2.

1701 BGE 130 I 312, at 4.1; BGE 136 I 290, at 2.3.2. See also BGE 135 V 339, at 5.3. The Court has distinguished between the methods of statutory interpretation and the methods 
Swiss legal order (Chapter 3, 2.2.1, supra), this conception is also reflected in the Court's statement that the four methods (textual, systematic, teleological, and historical, see also Chapter 6, supra) apply in the domestic legal order at large. ${ }^{1702}$ Though some cases could suggest a difference (or only a 'relative similarity' ${ }^{1703}$ between the methods of treaty interpretation and those of domestic law, ${ }^{1704}$ there is no indication in the case law that these methods are actually different. Rather, the disjunction to which the Court alludes concerns the idiosyncratic features of domestic and international lawmaking, respectively.

As a matter of fact, many features of the Court's case law on domestic methods confirm this convergence. In the domestic context, the Swiss Federal Tribunal considers that the various methods do not stand in any hierarchical relationship. ${ }^{1705}$ However, a provision cannot be interpreted contra legem, ${ }^{1706}$ unless weighty reasons justify it. ${ }^{1707}$ The Court has noted that it relies on the text alone in exceptional cases, when its meaning leaves no room for doubt. ${ }^{1708}$ It also relies on systematic ${ }^{1709}$ and teleological ${ }^{1710}$ arguments. It has highlighted the importance of subsequent interpretative practice to identify the meaning of written legal acts. ${ }^{111}$ This feature is reminiscent of the subsequent practice that is relevant in the context of treaty interpretation, as per art. 31(3)(b) VCLT. The Swiss Federal Tribunal acknowledges that historical interpretation is not decisive, but an 'interpretative aid.' ${ }^{1712}$ This position is consistent with the status of 'auxiliary means' of the travaux pursuant to art. 32 VCLT.

The case law confirms that interpretative methods are the same in domestic law and treaty law, even if some differences exist between domestic and international lawmaking (eg the characteristics of lawmaking bodies in domestic and international law, respectively). The fact that the Swiss Federal Tribunal, at

applicable to contractual interpretation, although it applies the methods of statutory interpretation to the bylaws of large corporations, see BGE 14 O III 349, at 2.3.

1702 BGE 83 IV 121 , at 2 .

1703 BGE 136 I 290, at 2.3.2; BGE 135 V 339, at 5.3; BGE 130 I 312, at 4.1.

1704 BGE 110 Ia 123 , at 1.

1705 BGE 141 III 155, at 4.2; BGE 139 III 225, at 2.2; BGE $131 \mathrm{~V} 305$, at 4.4; BGE 123 II 595, at 4 a); BGE 98 Ia 194, at 2 a); BGE 83 I 173, at 4; BGE 131 II 697, at 4.1.

1706 вGE 98 Ia 194, at 2 a). See also BGE 83 I 173 , at 4.

1707 BGE $118 \mathrm{Ib} \mathrm{187}$, at 5 a); BGE 141 II 262, at 4.2; BGE 113 V 150, at 3 a).

1708 BGE 131 II 697 , at 4.1.

1709 BGE 129 III 656, at 4.2.2.

1710 On teleological interpretation, see вGE 128 I 34, at 3 b). See also BGE 123 III 442, at 2 d); BGE 129 III 656, at 4.3 .

1711 BGE 83 I 173, at 4 . See also BGE 116 Ia 359, at 5 c).

1712 BGE 141 III 155, at 4.2; BGE 123 II 595, at 4 a). See also BGE 83 I 173, at 4, and BGE 83 IV 121 , at 2, where the Court analyzes historical interpretation in detail. 
times, compares the methods of treaty interpretation with domestic law, suggests that the Court draws on (and is influenced by) methodological insights gained in the context of domestic interpretation when it interprets treaties. Vice versa, the Court has used the methods of treaty interpretation to interpret some domestic laws, especially intercantonal agreements (eg supra, 3.1).

\subsection{Comparing the Practice of Swiss Courts}

The preceding survey of Swiss courts' practice of treaty interpretation (supra, 3.1-3.3) opens the doors for a comparison of their respective approaches.

The Swiss Federal Tribunal's case law is cited and followed by all Swiss courts under scrutiny. While this practice is not necessarily the oldest, given the longstanding activity of cantonal courts, it is by far the most easily accessible, and it covers the longest period of time. These practical considerations aside, relevant judgments of other courts are much scarcer, except for the SFAC's. The Swiss Federal Tribunal's appellate function in the Swiss judiciary largely explains the Court's interpretive authority. This authority also hinges on other factors, including the breadth of the Court's jurisdiction (contrary to the narrow jurisdiction of the SFCC, for instance), the range of treaties the Court has interpreted, and the detailed guidance it provides on interpretative methods regarding specific treaties (eg the Swiss-EU Agreement on the Free Movement of Persons), but also more generally (by endorsing the VCLT's methods). Other courts tend to provide more precise interpretations in politically sensitive cases only, eg the SFCC in Nezzar, or the SFAC in cases pertaining to DTAS and the UBs Agreement.

Only the SFAC's practice is as detailed as (and, occasionally, more detailed than) the Swiss Federal Tribunal's. This is especially the case when the SFAC interprets DTAs and the UBS Agreement. The Court has been more thorough than the Swiss Federal Tribunal when assessing the customary character of the VCLT's methods, and when determining whether the VCLT has codified or crystallized custom, for instance. It is also more explicit in its endorsement of 'pragmatic methodological pluralism' in the context of international law. On the other hand, its case law is more specialized than the Swiss Federal Tribunal's and, at times, more ambiguous and contradictory. This is for example the case when the SFAC uses the practice of the Swiss authorities to interpret a treaty, but does not accept such unilateral interpretations when they are based on the practice of Switzerland's treaty partners.

While the sophistication and precision of the Swiss Federal Tribunal's case law has increased over time, its recent practice also comes with flaws from the perspective of interpretative methods and good judicial reasoning. Recurring problems include repetitive tendencies, a lack of genuine engagement with 
the legal act and its characteristics in some cases (eg when the Court simply relies on art. 31(1) VCLT, or when it primarily uses scholarship to underpin its interpretative conclusions), circularity (ie, references to the Court's own interpretations), and self-referentiality (ie, references to the practice of other Swiss courts and authorities). Moreover, in some instances, its practice is squarely at odds with the VCLT. One common mistake pertains to the use of domestic legislative history (especially the dispatch of the Federal Council) to interpret treaties.

These problematic features can be found in the practice of all courts under scrutiny, to the extent that their case law is detailed enough. Most courts have endorsed the customary character of the VCLT's methods, and many have noted the congruence that exists between the interpretative methods of domestic written law and those of treaties. Courts also acknowledge the duty of States to interpret treaties in good faith and independently from domestic law. However, some courts, like the SFCC, hardly ever refer to the vCLT. Swiss courts barely depart from the path traced by the Swiss Federal Tribunal. They often strive to demonstrate that their case law is consistent with it. Exceptionally, cantonal jurisdictions have adopted unorthodox approaches, eg by engaging in contractual interpretation or by mentioning restrictive interpretation.

Swiss courts' interpretative methods are particularly detailed with regard to DTAs, the Swiss-EU Agreement on the Free Movement of Persons, and social security agreements. The courts tend to adopt idiosyncratic interpretative approaches in different substantive areas of international law. With regard to the Swiss-EU Agreement on Free Movement, for instance, the Swiss Federal Tribunal (followed by other Swiss courts) tends to emphasize purposive interpretation. ${ }^{1713}$ Its approach is less markedly teleological for other treaties. Independently from the characteristics of different regimes and from the fact that not every case raises complex interpretative issues, courts do not seem to use a predictable, clear, and consistent interpretative scheme across cases.

The Swiss Federal Tribunal occasionally uses the practice of other Swiss authorities, especially that of the Swiss Federal Council. Other Swiss courts tend to follow the Swiss Federal Tribunal, and they typically neglect the practice of other State organs, including the executive. All Swiss courts make scarce use of foreign and international case law. One exception is the case law of the ECtHR, which is often (and sometimes extensively) cited by the Swiss Federal Tribunal in relevant cases. ${ }^{1714}$ Most courts use scholarship which, sometimes,

1713 On this issue, see already Besson and Ammann (n 97) 340 ff.

1714 For a detailed analysis, see Ammann, "The European Court of Human Rights and Swiss Politics: How Does the Swiss Judge Fit In?' (n 1369). 
is even their only resource. This casts doubt on whether they have thoroughly engaged with the practice on a given issue, especially when few authors are cited.

Many other empirical causes likely explain some of the variations in the case law (eg the composition of a court in different cases). Their in-depth examination is beyond the scope of this study.

\subsection{Putting the Swiss Judicial Practice into Perspective}

The survey of the Swiss judicial practice also makes it possible to compare ${ }^{1715}$ this practice with that of other domestic courts.

The Swiss case law resembles that of other domestic courts in many respects. Shared features include the endorsement of the VCLT's methods qua customary law, but also a tendency to refer to these methods selectively, or without necessarily following through. Courts also tend to not always explicitly acknowledge the mandatory character of these methods. They rely on their own precedents, and they provide little detail as to their interpretative methodology. Their degree of diligence seems to hinge on the subject matter of the case. Finally, domestic courts sometimes disregard the constraints established by interpretative methods, eg by referring to domestic (but not to intergovernmental) preparatory work that pertains to the ratification of a specific treaty.

In other regards, the Swiss judicial practice differs from that of foreign courts. Swiss judges seem to consider interpretative methods to be obligatory, unlike other judges, especially judges in jurisdictions that are not parties to the vCLT. Another difference is that the Swiss Federal Tribunal is keener to use these methods than other Swiss (and especially cantonal) courts, unlike in the United States for instance, where the Supreme Court is reluctant to use these methods, contrary to the lower courts. Swiss courts are also less inclined to cite foreign materials (eg foreign judgments). This is likely partly due to the laconic style of Swiss rulings, and to the absence of separate opinions in the Swiss judiciary (see supra, Chapter 3, 4.2.5).

1715 Of course, as previously mentioned (supra, 2.1), comparability is limited by the layer of domestic constitutional law that inevitably conditions domestic courts' interpretations, by the scarcity of material available for some foreign jurisdictions, and by the fact that the scope of this project precluded analyzing these practices with the same level of detail as the Swiss case law. 
While Swiss courts sometimes diligently follow the methods of treaty interpretation, some features of their practice are problematic from the perspective of legality and high-quality reasoning (supra, Introduction, section 3). I identify four clusters of problems.

1. Neglect of interpretative methods. Courts tend to ignore the methods of treaty interpretation. This omission is either systematic, frequent, or occasional (eg only in connection with specific treaties). It ranges from full neglect to the neglect of only some methods (which usually goes along with biases in favor of other methods) and the conditions under which they apply (eg art. 32 VCLT). Cantonal courts hardly refer to treaty interpretation and its methods. Another symptom of this neglect is that the courts have used concepts that are not required by the interpretative methods of international law, eg effet utile and restrictive interpretation, and domestic concepts and categories. Finally, courts are sometimes hesitant to embrace the customary character of some methods, and they mention Switzerland's ratification of the VCLT to justify their applicability.

To ignor interpretative methods is particularly problematic from the perspective of legality. The less courts dwell upon their interpretative approach, the more difficult it is to evaluate whether their decisions have been reached in conformity with the law. Of course, not every case raises difficult interpretative issues, and it would be counter-productive to require courts to elaborate on their interpretative methodology in such instances. However, in many rulings, controversial interpretative issues do arise, which calls for a more careful approach to interpretative methods. The neglect of interpretative methods also creates difficulties from the vantage point of the quality of judicial reasoning. Indeed, in doing so, courts fail to reason predictably, clearly, and consistently.

2. Selective reliance on auxiliary means and insufficient substantiation. Courts often assert a given interpretation without substantiating this conclusion. Assertion is not necessarily problematic. It may be appropriate when a relatively straightforward legal issue is involved. However, assertion is deeply problematic when it is used to conceal a lack of methodological rigor. Such rigor is required from the perspective of both the legality and the quality of judicial reasoning. ${ }^{1716}$

1716 This type of assertion has been denounced by Stefan Talmon with regard to the ICJ's identification of customary international law; see Talmon (n 73). See also Ryngaert and Hora Siccama (n 229). 
A related feature of the case law is that courts tend to rely on auxiliary means, instead of direct manifestations of State practice on treaty interpretation. Again, using auxiliary means is not necessarily flawed, and it is in line with art. 38(1)(d) ICJ Statute. Yet the selective and sloppy resort to such means can lead courts to ignore the actual State practice, which (in CIL at least) must be coherent, constant, and general. It is hence potentially problematic from the perspective of legality. As a matter of fact, courts particularly often use legal scholarship, while neglecting the practice of their treaty partners, and international judicial decisions. Moreover, high-quality judicial reasoning requires that interpretations be backed by predictable, clear, and consistent reasoning.

3. Self-referentiality and circularity. The Swiss judicial practice is highly selfreferential (when courts cite other Swiss authorities) and even circular (when they cite themselves). Courts frequently rely on the interpretative practice of the Swiss authorities, especially the practice of Swiss courts. They particularly frequently rely on their own previous case law. This is, again, problematic from the perspective of the legality and quality of judicial reasoning. Indeed, it can lead to a disregard for the sources of international law and for the characteristics of international lawmaking (which, by definition, involves more than one Sate). It can also undermine the predictability, clarity, and consistency of judicial reasoning, since it may conceal a lack of transparency and of thorough engagement with the interpretative issue.

4. Imprecision, uneven level of detail, and superficial reasoning. Courts rarely apply the interpretative methods of treaty law in a systematic, detailed, and transparent way. The level of detail of their case law is uneven. Some remarks about the methods of treaty interpretation, though pedagogical and detailed, are highly repetitive. This suggests that courts do not actually engage with these methods, but merely pay lipservice to them. Again, it is important to stress that not every interpretative issue is complex and controversial. This explains the heterogeneity of the case law to a certain extent. Moreover, repetitive cases may be due to the fact that the basic interpretative issue at stake is essentially identical. On the other hand, superficial reasoning can create the sense that an issue is clear, even though it does raise interpretative issues. It also risks disregarding the sources and specificities of international law and of the issue at hand. Finally, it prevents predictable, clear, and consistent reasoning.

To conclude, in at least four respects, the Swiss judicial practice of treaty interpretation stands in tension with the methods of treaty interpretation and with high-quality reasoning. As I will show, these clusters of problems also arise, mutatis mutandis, in connection with unwritten international law (Chapter 8, section 4, infra). 